\title{
Isotopic evidence for phytoplankton as a major food source for macrobenthos on an intertidal sandflat in Ariake Sound, Japan
}

\author{
Hisashi Yokoyama ${ }^{1, *}$, Akio Tamaki ${ }^{2}$, Kazuki Koyama ${ }^{2}$, Yuka Ishihii ${ }^{1}$, \\ Katsumasa Shimoda ${ }^{2}$, Kazuyuki Harada ${ }^{2}$ \\ ${ }^{1}$ National Research Institute of Aquaculture, Fisheries Research Agency, Nansei, Mie 516-0193, Japan \\ ${ }^{2}$ Faculty of Fisheries, Nagasaki University, Bunkyo-Machi 1-14, Nagasaki 851-8521, Japan
}

\begin{abstract}
To delineate a soft-shore trophic structure, macrobenthos was collected from an intertidal sandflat at the mouth of the Shirakawa River in the central part of Ariake Sound, Kyushu, Japan, on 3 occasions in 2003 (January, March, and June to July during the rainy season), and the isotopic compositions of animals and their potential food sources were analyzed. Food sources of animals were assessed based on the diet - tissue isotopic fractionation $\left(\delta^{13} \mathrm{C}=0.6\right.$ to $2.0 \%, \delta^{15} \mathrm{~N}=3.4$ to $3.9 \%$ ) of 3 main constituent species (the bivalves Mactra veneriformis and Ruditapes philippinarum and the ghost shrimp Nihonotrypaea japonica), which had been determined by an earlier laboratory experiment. The results revealed that (1) consumers were classified into 3 groups; a group consisting of 51 species including 4 main species (the above-mentioned species and the mud shrimp Upogebia major) that derived nutrition mainly from coastal phytoplankton, one consisting of 7 species that incorporated more ${ }^{13} \mathrm{C}$-enriched material (e.g. benthic microalgae) and a group consisting of 4 species that incorporated more ${ }^{13} \mathrm{C}$-reduced material (e.g. riverine organic matter); (2) the phytoplankton-based trophic structure was composed of 3 trophic levels; (3) M. veneriformis juveniles collected during the rainy season appeared to incorporate riverine organic matter; and (4) reeds from the flood plain, detrital terrestrial plant material, sewage effluents and seaweeds were not food sources for most consumers. We concluded that the high phytoplankton biomass and scarcity of benthic microalgae on this sandflat account for its phytoplankton-based trophic structure.
\end{abstract}

KEY WORDS: Stable isotopes - Estuary · Intertidal sandflat - Trophic structure $\cdot$ Phytoplankton · Benthic microalgae

- Resale or republication not permitted without written consent of the publisher

\section{INTRODUCTION}

Intertidal flats constitute highly productive environments. This productivity has been considered to be largely due to the diversity and abundance of potential food sources for intertidal animals. To understand the energy and material flows in an estuarine ecosystem, it is necessary to identify the food sources of animals and to elucidate their trophic structure. However, it is difficult to obtain a composite understanding of this using direct observations of feeding behavior and stomach content analysis. These traditional techniques are difficult to apply to small invertebrates due to the minute fragmentation of foods. Even if these techniques were applicable, obtained information would be limited to food items that had just been ingested, and food assimilated over a longer period could not be determined (Sauriau \& Kang 2000).

The combined analysis of carbon and nitrogen stable isotope ratios is a powerful tool for investigating the trophic structure of terrestrial and aquatic ecosystems. The stable carbon isotope ratio $\left(\delta^{13} \mathrm{C}\right)$ has been used to determine sources and pathways of organic matter for animals, while the nitrogen stable isotope ratio $\left(\delta^{15} \mathrm{~N}\right)$ has been used to determine the trophic positions of organisms in food webs (reviewed by Fry \& Sherr 1984, 
Owens 1987, Peterson \& Fry 1987). This technique allows quick assessment of the origin of organic matter assimilation by animals and a broad overview of the mean trophic structure with limited sampling effort.

Based on isotopic studies, the relative importance of various food sources that could potentially fuel estuarine food webs has been debated. For instance, several investigations have revealed the potential for vascular plants in wetlands (e.g. Wainright et al. 2000), riverine terrestrial organic matter (e.g. Incze et al. 1982, Kikuchi \& Wada 1996, Riera \& Richard 1996, 1997, Fry 1999), seaweeds (e.g. Adin \& Riera 2003), seagrass detritus (e.g. Fry \& Parker 1979) and anthropogenic effluents (e.g. Lee 2000) to play a significant role in estuarine food webs. Of these case studies, most have noted the importance of phytoplankton (e.g. Yelenik et al. 1996, Mulkins et al. 2002), seagrass epiphytes (e.g. Moncreiff \& Sullivan 2001) and benthic microalgae. In recent years, increased attention has been paid to benthic microalgae as a food source for meiobenthos (Couch 1989, Riera et al. 1996) and macrobenthos (Sullivan \& Moncreiff 1990, Currin et al. 1995, Créach et al. 1997, Riera et al. 1999, Kang et al. 1999, 2003, Herman et al. 2000, Sauriau \& Kang 2000, Page \& Lastra 2003) living on intertidal flats.

The stable-isotope approach is based on the assumptions that (1) there are a limited number of potential food sources each with a distinct isotopic composition and (2) isotopic fractionation from one trophic level to the next is predictable. In general, intertidal environments receive a number of potential food sources such as natural and anthropogenic inputs of terrestrial and riverine organic matter coming from freshwater inflow, coastal phytoplankton entrained by tidal currents and autochthonous benthic micro- and macroalgal productions. Moreover, the actual degree of the diet-tissue isotopic fractionation has been found to vary (Gearing et al. 1984, Vander Zanden \& Rasmussen 2001, McCutchan et al. 2003, Yokoyama et al. 2005). In these cases, quantification of the relative abundance of the food sources and exact diet-tissue fractionation for each constituent species will provide more precise information.

Intertidal flats in Ariake Sound, western Kyushu, Japan, are characterized by high production and a large variety of species (Sato 2000, Nakata 2004, Sato \& Koh 2004). A typical sandflat of Ariake Sound extends around the mouth of the Shirakawa River (hereafter Shirakawa sandflat), where a succession of dominant species has occurred during the last $30 \mathrm{yr}$ (Wardiatno et al. 2003, Tamaki 2004a,b). Identification of the food sources for these animals and associated macrofauna will provide basic information for clarifying the mechanism of the observed faunal succession.
The aim of the present study is to assess the food sources of intertidal animals and to delineate the trophic structure of the Shirakawa sandflat by comparing their stable isotope composition $\left(\delta^{13} \mathrm{C}\right.$ and $\left.\delta^{15} \mathrm{~N}\right)$ with those of their potential food sources during different periods of the year affected by different amounts of precipitation. The diet-tissue isotopic fractionation for 3 constituent species (Ruditapes philippinarum, Nihonotrypaea japonica and the mactrid bivalve Mactra veneriformis) that had been determined by an earlier laboratory feeding experiment (Yokoyama et al. 2005) were used for the food source analysis. This experiment has demonstrated that the fractionation is species-specific and that the currently accepted diet-tissue isotopic fractionation values (i.e. 0 to $1 \%$ for carbon and 3 to $4 \%$ or nitrogen) are not applicable to all animals and/or ecological systems.

\section{MATERIALS AND METHODS}

Study area. Ariake Sound is a semi-enclosed bay with an area of $1700 \mathrm{~km}^{2}$ and a mean depth of $20 \mathrm{~m}$ (Fig. 1). The bay is characterized by a large tidal amplitude ranging from $\sim 3 \mathrm{~m}$ at the mouth of the sound (Hayasaki Inlet) to $\sim 6 \mathrm{~m}$ at the head of the bay. Several large rivers flow into the northern to eastern coast, from Saga to Kumamoto, carrying large amounts of sediment. These features generate extensive tidal flats covering a total area of $231 \mathrm{~km}^{2}$ in the bay.

Field surveys were conducted on the Shirakawa sandflat $\left(32^{\circ} 47^{\prime} \mathrm{N}, 130^{\circ} 36^{\prime} \mathrm{E}\right)$, which is located in the central part of the eastern coast of Ariake Sound (Fig. 1). The sandflat expands over the area between the mouths of the Shirakawa and Tsuboigawa Rivers and is bound by a seawall (= high-tide shoreline, Stn C in Fig. 1) above which rice paddies and vegetable farms are distributed. The Shirakawa River originates from the Aso caldera situated in the central part of Kyushu Island, drains a $480 \mathrm{~km}^{2}$ area and flows through Kumamoto City and satellite towns, an area populated by approximately 1 million people. There are 3 sewage treatment plants along the Shirakawa River, 2 plants located on the middle or lower river and 1 located at its mouth. The reed Phragmites communis occurs abundantly on the flood plain at the lowest sections of the river.

The Kumamoto Office of Rivers and National Highways continuously records the precipitation in the drainage area of the Shirakawa River and the river flow rate. The precipitation at Shikimi (headwaters of the river) and the flow rate at Yotsugi-bashi (the lower part of the river) during the study period were as follows (Ministry of Land, Infrastructure and Trans- 


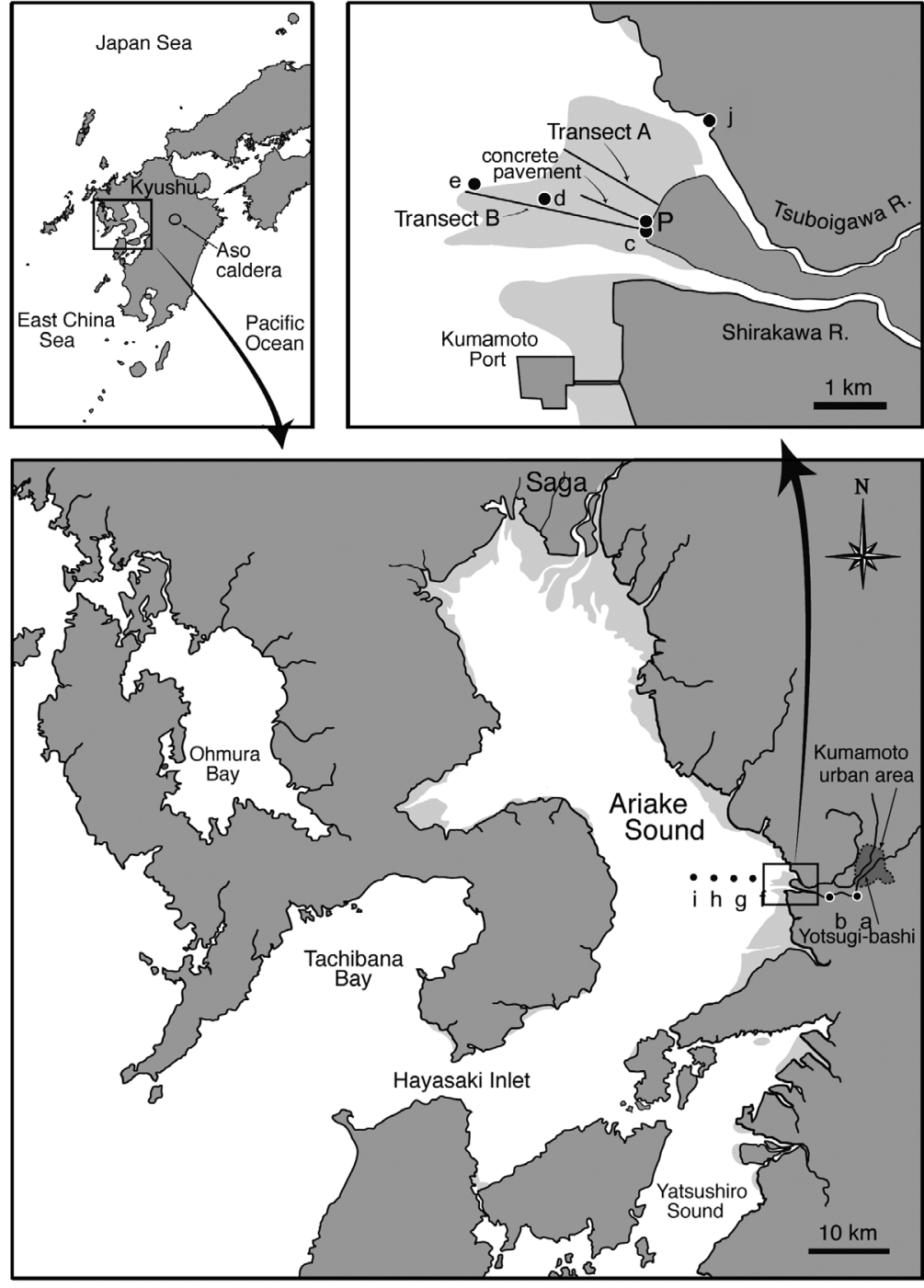

Fig. 1. Study area. Location of the Shirakawa sandflat, 2 transects (A and B) along which animals and sediments were sampled and 10 stations for water sampling (Stns a-j). Light gray areas: intertidal zone to its extreme low-water spring tide level

port, unpubl. data): until the middle of June, the flow rate before any rainfall was $\sim 15 \mathrm{~m}^{3} \mathrm{~s}^{-1}$, and it increased following each rainfall, but rarely exceeded $50 \mathrm{~m}^{3} \mathrm{~s}^{-1}$ during the rainy season, from mid June through the end of July, precipitation often exceeded $30 \mathrm{~mm} \mathrm{~d}^{-1}$, resulting in increased flow rates that remained $>30 \mathrm{~m}^{3}$ $\mathrm{s}^{-1}$ throughout most of this period; in particular, the area was hit by heavy rainfall on July 12, 2003, when precipitation amounted to $323 \mathrm{~mm} \mathrm{~d}^{-1}$ and the flow rate reached $461 \mathrm{~m}^{3} \mathrm{~s}^{-1}$.

Tides in the study area are semidiurnal, and the average tidal amplitudes at the spring and neap tides are 4.0 and $2.0 \mathrm{~m}$, respectively. At the lowest spring tide, an area of $4.1 \mathrm{~km}^{2}$ of the intertidal zone emerges. The inclination along the intertidal gradient is approximately $1 / 1000$ to $1 / 800$ (Wardiatno et al. 2003, Yamada and Kobayashi 2004). The maximum duration of exposure per low tide ranges from 3.1 to $8.7 \mathrm{~h}$ (Wardiatno et al. 2003). The sandflat is entirely bare, except for small amounts of seaweeds occasionally found attached to small stones. The volcanic sand generated from Aso volcanoes, Yona in local Japanese, which is composed of coarse-grained inadhesive particles with high permeability, is transported by flow from the Shirakawa River and forms the Shirakawa sandflat (Suetsugi et al. 2002). The median diameter of sediments in the surface layer (0 to $1 \mathrm{~cm}$ depth) of the sandflat is in the range 1.1 to $3.1 \varphi$ ( 0.12 to $0.47 \mathrm{~mm})$, and the mud content ( $\%$ by weight of sediment $<0.063 \mathrm{~mm}$ in diameter) usually ranges from 0.9 to $22.6 \%$ (Wardiatno et al. 2003) but occasionally reaches $50 \%$ after floods (Tamaki 2004a). Around the lowermost shore, allochthonous sand with coarser grains containing shell fragments was spread on the sandflat in 2001 and earlier by the local fishery cooperative association to enhance the settlement of the Ruditapes philippinarum spat. The allochthonous sand area occupies a zone 1260 to $1420 \mathrm{~m}$ from the seawall along sampling Transect $A$, and 1970 to $2130 \mathrm{~m}$ along Transect B (Fig. 1). Both transects run from the seawall to the mean low water spring tide level, with a length of $1500 \mathrm{~m}$ and $2100 \mathrm{~m}$, respectively. A concrete pavement $4 \mathrm{~m}$ wide, which lies between the 2 transects, was constructed in 1984 to carry harvested clams.

The substrate conditions are temporally unstable. Accretion and erosion of sediments occur through the year; the former event occurs during summer and the latter during winter due to the combined effects of tides and wind-induced waves (Yamada \& Kobayashi 2004). Inflow of a large amount of sediment associated with increased river flow can also produce accretion of sediment (Suetsugi et al. 2002, Yamamoto et al. 2003).

The present status and a possible succession scenario of macrofauna during the last $30 \mathrm{yr}$ based on interviews with local fishermen and our own recent surveys have been previously described (Wardiatno et al. 2003, Tamaki 2004a,b, A. Tamaki unpubl. data). Details are as follows: a dense population of Ruditapes philippinarum has declined since the early 1980s; in 
the $1970 \mathrm{~s}, R$. philippinarum was distributed over the entire sandflat in extremely high densities; in recent years, however, the habitat range of this clam has been confined to the lower tidal zone, where a maximum density of 550 individuals $\mathrm{m}^{-2}$ occurs. Meanwhile, the ghost shrimp Nihonotrypaea japonica has increased its population size and occurs as a dominant species on the upper and middle tidal zone with maximum densities of 294 to 373 individuals $\mathrm{m}^{-2}$. Coincident with the $N$. japonica population growth, the ground has become softer (less compact) and more unstable due to the construction of burrows, which may have accelerated the decline of the $R$. philippinarum population. The mud shrimp Upogebia major (Decapoda: Upogebiidae), another large biotrubating species (Kinoshita et al. 2003), has also increased its population size, attaining maximum densities of 6.5 to $40.0 \mathrm{~m}^{-2}$. The bivalve Mactra veneriformis occurs widely along the transects, including the ghost shrimp zone, with a maximum density of 150 individuals $\mathrm{m}^{-2}$.

Sample collection. Intertidal macrobenthos was collected from stations along the 2 transects (A, B) on the Shirakawa sandflat during the daytime low tide at the spring tides on January 21, March 18 and 20, June 29 and 30, and July 12 and 14, 2003 (Fig. 1). The rainy season in this year was reported to be from June 9 through July 31 (Japan Meteorological Agency broadcast in 2003). Larger specimens were collected by hand or a handheld net and smaller ones by sieving sediments with a $1 \mathrm{~mm}$ mesh sieve. Potential food sources for intertidal animals in the study area include particulate organic matter (POM) in seawater of Ariake Sound (estuarine POM), POM in river water (riverine POM), POM in effluents from sewage treatment plants (sewage POM), sedimentary organic matter on the sandflat (SOM), detrital terrestrial plant material, benthic microalgae, and seaweeds.

To analyze the isotopic compositions of estuarine POM, a sample of seawater was taken from the $2.5 \mathrm{~m}$ depth layer at Stn e (the lowest tide line during the year, $2.5 \mathrm{~km}$ from the seawall) and the $5.0 \mathrm{~m}$ depth layer at Stns f (5.0 km from the seawall), $g(7.5 \mathrm{~km}), \mathrm{h}$ $(10.0 \mathrm{~km})$ and $\mathrm{i}(12.5 \mathrm{~km})$ with a Van Dorn water sampler during high tide on March 20 and August 5. For the analysis of riverine POM, a sample of surface river water was obtained from $\mathrm{Stn}$ a $(7.6 \mathrm{~km}$ from the river mouth, salinity $<0.2$; all salinity values given hereafter were determined with a salinometer, YSI Model 85 handheld system, YSI) and/or Stn b (5.6 km, salinity < 0.2) in the Shirakawa River on January 21, March 21 and July 12. For the analysis of sewage POM, 2 samples of discharged water running through the underground drain pipe from the plant were obtained at an outlet of the drain pipe located at the mouth of the Tsuboigawa River (Stn j) on May 6, 2004.
For the analysis of SOM, surface sediments to a depth of $1 \mathrm{~cm}$ were collected from a total of 13 stations located along Transects A and B on March 18 and 20 and from 13 stations from Transect B on July 14. Each sampling station is denoted as A1340, B0, B1970, etc; the numerals following A or B (transects) indicate the distance from the seawall (m). At the time of the July survey, we found depositions of large amounts of flood-derived muddy sediments.

When a mosaic of neighboring basal sand and newly deposited mud from place to place along the transects was observed, a representative sediment sample was collected for each sediment type (at 4 stations). At the same time, plenty of terrestrial plant fragments composed mainly of dead leaves, twigs and pieces of grass had been carried by the river and drifted onto the sandflat. These detrital terrestrial plant materials were also collected. Standing dead flowering heads, leaves and stalks, decayed rootstock and live rootstock of the reed Phragmites communis were collected on January 21,2003 . Benthic microalgae were extracted from the surface sediments (depth $=0$ to $1 \mathrm{~cm}$ ) collected at the same time as in the SOM sampling (March 18 and 20, and July 14) following the procedure given in Couch (1989) as modified by Riera \& Richard (1996). Samples for benthic microalgae were also collected from the uppermost $30 \mathrm{~m}$ part of the concrete pavement close to the seawall, to which muddy sediment deposition was limited along the pavement (Stn P). A small portion of each microalgal sample collected in March was preserved in $10 \%$ neutralized formalin and later examined under a microscope to identify the species composition. Seaweeds attaching to hard substrata or drifted ashore were collected when encountered on the sandflat. Sampling dates for each animal and its potential foods are given in Table 2.

Measurements of non-isotopic environmental parameters. The river water and seawater collected for the isotopic analysis were subsampled and used for salinity and chlorophyll a (chl a) concentration measurements. The seawater obtained at the seawall (Stn c) and the middle tidal zone (Stn d: $1.5 \mathrm{~km}$ from seawall) was also used for chl a analysis. During the highest tide, seawater was obtained from the surface of the water at Stn $c_{\text {, }}$ and from depths of 0, 1.0, 2.0 and $2.5 \mathrm{~m}$ at Stn $\mathrm{d}$ with its depth of $2.7 \mathrm{~m}$. Following Parsons et al. (1984), chl a concentration of the water sample was determined by photofluorometry (10-AU Fluorometer, Turner Designs), in which pigment extraction was made with $N, N$-dimethylformamide (Suzuki \& Ishimaru 1990).

The sediments collected for the isotopic analysis were also used for the measurement of the total organic carbon and total nitrogen contents, which were determined using an elemental analyzer (EA 1110, 
ThermoQuest Italia). Sediments that were used for the measurement of chl a concentration were collected from substrata (area $=100 \mathrm{~cm}^{2}$, depth $=0$ to $1.0 \mathrm{~cm}$ ) just adjacent to the stations where sediments for the analyses of the isotopic compositions and benthic microalgae were collected. The sediment samples were preserved in ice in plastic bags that shielded them from light, transported to the laboratory and kept frozen until analysis. Chl a concentration of the sediment sample was also determined by photofluorometry. The seawater introduced into the laboratory through a sand filter was further filtered through Whatman GF/F glass fiber filters twice. Filtered seawater was added to the whole sediment sample up to $500 \mathrm{ml}$ in a graduated measuring cylinder. Then both sediment and seawater were stirred well to generate a uniformly suspended mixture, from which a $10 \mathrm{ml}$ subsample was pipetted off and filtered through a GF/F filter. This filter sample was used for the extraction of chl a.

Sample processing for isotopic analysis. The collected animals were transported to the laboratory, kept overnight in filtered seawater to allow evacuation of intestine contents and kept frozen until analysis, at which time they were thawed. For the mollusks, the shell was removed and the whole soft tissues were used as the sample. For the decapod crustaceans, muscle tissue was extracted from abdominal segments or pereiopods (Yokoyama et al. 2005). The other crustaceans (cirripeds and amphipods) and animals of other taxonomic groups (actinian, nemertineans, brachiopod, polychaetes, holothurian, ascidian and teleosts) were analyzed whole. The animal tissues were soaked in 1.2 N HCl for a few minutes to remove traces of carbonates, dried at $60^{\circ} \mathrm{C}$ and ground to a fine powder.

The seawater, river water and discharged sewagetreated water were passed through a $0.125 \mathrm{~mm}$ mesh net to remove large particles including zooplankton and filtered on precombusted Whatman GF/F glass fiber filters, washed with $1.2 \mathrm{~N} \mathrm{HCl}$, rinsed with distilled water, and dried at $60^{\circ} \mathrm{C}$. The sediments were soaked in $1.2 \mathrm{~N} \mathrm{HCl}$ overnight to remove carbonates, dried at $60^{\circ} \mathrm{C}$ and powdered. The detrital terrestrial plant materials were rinsed with distilled water, dried at $60^{\circ} \mathrm{C}$ and powdered. The seaweeds were washed with $1.2 \mathrm{~N} \mathrm{HCl}$, rinsed with distilled water, dried at $60^{\circ} \mathrm{C}$ and powdered.

The ${ }^{15} \mathrm{~N}$ and ${ }^{13} \mathrm{C}$ composition of the samples was determined using a mass spectrometer (MAT 252, Finnigan MAT) and coupled online via a Finnigan ConFlo II interface with the elemental analyzer. Results are expressed in the standard $\delta$ unit notation as $\delta X=\left[\left(R_{\text {samples }} / R_{\text {reference }}\right)-1\right] \times 10^{3}$, where $X$ is ${ }^{13} \mathrm{C}$ or ${ }^{15} \mathrm{~N}$ and $R={ }^{13} \mathrm{C} /{ }^{12} \mathrm{C}$ for carbon and ${ }^{15} \mathrm{~N} /{ }^{14} \mathrm{~N}$ for nitrogen. The standard reference materials were Pee Dee Belemnite standard (PDB) for carbon and atmospheric $\mathrm{N}_{2}$ for nitrogen.

\section{RESULTS}

\section{Isotopic compositions of potential food sources}

The salinity of the water samples increased from Stn e (30.5 in March and 28.1 in August) to the offshore stations, but the values were relatively constant at Stns $g, h$ and $i$ at $~ 32.5$ in March and 30.3 in August. The bulk of POM collected from Stns $g$, h and i was coastal phytoplankton, which consisted mainly of centric diatoms such as Skeletonema costatum and Rhizosolenia setigera (Table 1). Thus, the $\delta^{13} \mathrm{C}$ and $\delta^{15} \mathrm{~N}$ values obtained from these 3 stations (i.e. $-20.0 \pm 0.1 \%$ and $7.2 \pm 0.2 \%$ in March, and $-17.9 \pm 0.2 \%$ and $7.5 \pm 0.6 \%$ in August, respectively) were regarded as the most marine signatures in this estuary (estuarine POM). The overall mean $( \pm \mathrm{SD}) \delta^{13} \mathrm{C}$ and $\delta^{15} \mathrm{~N}$ values of estuarine POM during the study period were $-19.0 \pm 1.2 \%$ and $7.3 \pm 0.4 \%$, respectively (Table 2 ) .

Although we tried to extract benthic microalgae from a total of 32 samples, we could obtain only 3 pairs of reliable $\delta^{13} \mathrm{C}$ and $\delta^{15} \mathrm{~N}$ values, which were confirmed from the detectable range of the mass spectrometer and from microscopic examinations. These samples were obtained from muddy sediments overlying the concrete pavement (Stn P) in January and March and

Table 1. Species composition of microflora. Samples were collected on March 20, 2003, for the isotopic analysis of estuarine particulate organic matter (POM) and benthic microalgae. Values in parentheses indicate the percentage of the total microalgal cells. For sampling stations, see Fig. 1. Stn A1340 refers to the station $1340 \mathrm{~m}$ from the seawall on Transect A

\begin{tabular}{|lcc|}
\hline Estuarine POM (Stns g-i) & Benthic microalgae (Stn A1340) & Benthic microalgae (Stn P) \\
\hline Skeletonema costatum (67) & Amphora spp. (33) & Navicula spp. (79) \\
Rhizosolenia setigera (18) & Navicula spp. (32) & Nitzschia spp. (8) \\
unidentified Cryptophyceae (3) & Nitzschia pellucida (18) \\
Eutreptiella sp. (3) & Bacillaria socialis (6) & Cylindrotheca closterium (7) \\
Leptocylindrus antarcticus (2) & Cylindrotheca closterium (4) & Amphora spp. (3) \\
Others (7) & Others (7) & Nitzschia reversa (2) \\
\end{tabular}


Table 2. Isotopic compositions of consumers and their potential food sources. The mean $\pm \mathrm{SD}(\mathrm{n} \geq 3$ ) or the range (n=2) of the $\delta^{13} \mathrm{C}$ and $\delta^{15} \mathrm{~N}$ values obtained during the study period are shown. Numbers in parentheses refer to species identification number. Trophic types of the consumers are Pp: phytoplankton-based primary consumer, Pps: phytoplankton-based primary to secondary consumer, Ps: phytoplankton-based secondary consumer, E: consumer that incorporates ${ }^{13} \mathrm{C}$-enriched material, R: consumer that incorporates ${ }^{13} \mathrm{C}$-reduced material (see text for details). $\mathrm{n}$ : sample size for the $\delta^{13} \mathrm{C}$ and $\delta^{15} \mathrm{~N}$ analysis. Sampling dates are Ja: January 21, 2003, Mr: March 18 or 20, 2003, Jn: June 29 or 30, 2003, Jl: July 12 or 14, 2003, Ag: August 5, 2003 and My: May 6, 2004

\begin{tabular}{|c|c|c|c|c|c|}
\hline Species or organic matter & $\begin{array}{l}\text { Trophic } \\
\text { type }\end{array}$ & $\begin{array}{l}\delta^{13} \mathrm{C} \\
(\% \circ)\end{array}$ & $\begin{array}{l}\delta^{15} \mathrm{~N} \\
(\% \circ)\end{array}$ & $\mathrm{n}$ & $\begin{array}{c}\text { Sampling } \\
\text { date }\end{array}$ \\
\hline \multicolumn{6}{|l|}{ Consumers } \\
\hline \multicolumn{6}{|l|}{ Cnidaria } \\
\hline \multirow{2}{*}{\multicolumn{6}{|c|}{ Nemertinea }} \\
\hline & & & & & \\
\hline \multicolumn{5}{|l|}{ Brachiopoda } & $\mathrm{Mr}$ \\
\hline (3) Lingula unguis & $\mathrm{Pp}$ & -19.2 & 10.7 & 1 & $\mathrm{Jl}$ \\
\hline \multicolumn{6}{|l|}{ Gastropoda } \\
\hline (4) Batillaria cumingii & $\mathrm{E}$ & -12.8 & 10.7 & 1 & Ja \\
\hline (5) Euspira fortunei & Pps & -17.3 to -17.2 & 12.5 to 13.2 & 2 & $\mathrm{Jn}, \mathrm{Jl}$ \\
\hline (6) Glossaulax didyma & Pps & $-17.6 \pm 0.3$ & $11.9 \pm 0.4$ & 6 & $\mathrm{Mr}, \mathrm{Jn}$ \\
\hline (7) Thais clavigera & Pps & $-18.2 \pm 0.5$ & $12.6 \pm 0.4$ & 5 & $\mathrm{Mr}, \mathrm{Jl}$ \\
\hline (8) Rapana venosa & Pps & -16.3 & 13.2 & 1 & $\mathrm{Mr}$ \\
\hline (9) Mitrella martensi & Pps & $-17.0 \pm 0.5$ & $12.9 \pm 0.3$ & 5 & $\mathrm{Mr}$ \\
\hline (10) Reticunassa festiva & Pps & $-16.8 \pm 0.4$ & $12.9 \pm 0.3$ & 15 & $\mathrm{Ja}, \mathrm{Mr}, \mathrm{Jl}$ \\
\hline (11) Armina babai & Ps & -15.5 & 15.4 & 1 & $\mathrm{Mr}$ \\
\hline \multicolumn{6}{|l|}{ Bivalvia } \\
\hline (12) Scapharca kagoshimensis & $\mathrm{Pp}$ & $-18.0 \pm 0.5$ & $11.6 \pm 0.2$ & 5 & $\mathrm{Mr}$ \\
\hline (13) Modiolus metcalfei & $\mathrm{Pp}$ & $-17.8 \pm 0.2$ & $11.2 \pm 0.2$ & 5 & $\mathrm{Mr}$ \\
\hline (14) Atrina lischkeana & $\mathrm{Pp}$ & $-18.2 \pm 0.3$ & $10.7 \pm 0.2$ & 6 & $\mathrm{Mr}$ \\
\hline (15) Anomia chinensis & $\mathrm{Pp}$ & $-17.9 \pm 0.2$ & $11.1 \pm 0.2$ & 5 & $\mathrm{Mr}$ \\
\hline (16) Crassostrea gigas & $\mathrm{Pp}$ & $-19.7 \pm 0.4$ & $10.3 \pm 0.4$ & 15 & $\mathrm{Ja}, \mathrm{Mr}, \mathrm{Jl}$ \\
\hline (17) Mactra veneriformis (adult) ${ }^{\mathrm{a}}$ & $\mathrm{Pp}$ & $-17.6 \pm 0.4$ & $11.4 \pm 0.4$ & 119 & $\mathrm{Ja}, \mathrm{Mr}, \mathrm{Jn}$ \\
\hline$\left(17^{\prime}\right)$ Mactra veneriformis (juvenile) ${ }^{b}$ & & $-19.0 \pm 0.2$ & $8.3 \pm 0.1$ & 7 & $\mathrm{Jl}$ \\
\hline (18) Solen strictus & $\mathrm{Pp}$ & $-17.9 \pm 0.3$ & $11.4 \pm 0.1$ & 5 & $\mathrm{Ja}, \mathrm{Mr}, \mathrm{Jn}$ \\
\hline (19) Peregrinamor ohshimai & $\mathrm{R}$ & -21.5 & 9.4 & 1 & $\mathrm{Mr}$ \\
\hline (20) Ruditapes philippinarum & $\mathrm{Pp}$ & $-18.3 \pm 0.4$ & $10.7 \pm 0.4$ & 50 & $\mathrm{Mr}, \mathrm{Jn}$ \\
\hline (21) Meretrix lusoria & $\mathrm{Pp}$ & $-19.0 \pm 0.6$ & $10.4 \pm 0.4$ & 18 & $\mathrm{Mr}, \mathrm{Jn}$ \\
\hline (22) Cyclina sinensis & Pps & $-19.0 \pm 0.2$ & $12.0 \pm 0.1$ & 4 & $\mathrm{Jn}, \mathrm{Jl}$ \\
\hline (23) Venatomya truncata & $\mathrm{Pp}$ & $-18.8 \pm 0.3$ & $10.5 \pm 0.3$ & 13 & $\mathrm{Mr}, \mathrm{Jn}, \mathrm{Jl}$ \\
\hline \multicolumn{6}{|l|}{ Polychaeta } \\
\hline (24) Armandia sp. & Ps & $-16.7 \pm 0.2$ & $15.4 \pm 0.4$ & 3 & $\mathrm{Mr}$ \\
\hline (25) Anaitides sp. & Pps & $-18.8 \pm 0.5$ & $13.0 \pm 1.1$ & 5 & $\mathrm{Mr}$ \\
\hline (26) Platynereis bicanaliculata & $\mathrm{R}$ & -19.7 & 13.9 & 1 & $\mathrm{Mr}$ \\
\hline (27) Tylorrhynchus sp. & $\mathrm{R}$ & -20.1 & 11.5 & 1 & $\mathrm{Jl}$ \\
\hline (28) Glycera macintoshi & Ps & $-16.2 \pm 1.2$ & $15.4 \pm 0.9$ & 5 & $\mathrm{Mr}, \mathrm{Jl}$ \\
\hline (29) Goniada sp. & Ps & -19.0 to -17.2 & 15.1 to 15.8 & 2 & $\mathrm{Mr}, \mathrm{Jl}$ \\
\hline (30) Nephtys caeca & Ps & -15.2 & 14.8 & 1 & $\mathrm{Jl}$ \\
\hline (31) Diopatra bilobata & Pps & $-17.9 \pm 0.3$ & $13.1 \pm 0.8$ & 4 & $\mathrm{Jl}$ \\
\hline (32) Unidentified Eunicidae & Pps & -18.1 & 12.4 & 1 & $\mathrm{Jl}$ \\
\hline (33) Owenia fusiformis & $\mathrm{Pp}$ & $-16.9 \pm 0.2$ & $11.1 \pm 0.3$ & 5 & $\mathrm{Mr}$ \\
\hline \multicolumn{6}{|l|}{ Crustacea } \\
\hline (34) Balanus albicostatus & Pps & $-18.5 \pm 1.0$ & $12.3 \pm 0.5$ & 12 & $\mathrm{Mr}, \mathrm{Jl}$ \\
\hline (35) Balanus kondakovi & Pps & $-18.3 \pm 0.3$ & $12.2 \pm 0.1$ & 3 & $\mathrm{Jl}$ \\
\hline (36) Harpiniopsis sp. & Pps & -17.6 & 13.5 & 1 & $\mathrm{Jl}$ \\
\hline (37) Unidentified Oedicerotidae & Pps & -17.3 to -16.9 & 11.3 to 12.2 & 2 & $\mathrm{Mr}$ \\
\hline (38) Urothoe sp. & $\mathrm{E}$ & -14.5 to -14.1 & 9.8 to 11.9 & 2 & $\mathrm{Jl}$ \\
\hline (39) Eriopisa sp. & $\mathrm{R}$ & -19.3 & 14.8 & 1 & $\mathrm{Jl}$ \\
\hline (40) Penaeus japonicus & Ps & -14.7 & 14.3 & 1 & $\mathrm{Mr}$ \\
\hline (41) Alpheus euphrosyne richardsoni & Ps & -15.9 & 13.7 & 1 & $\mathrm{Jl}$ \\
\hline (42) Chelomalpheus koreanus & Ps & -16.7 & 14.5 & 1 & $\mathrm{Mr}$ \\
\hline (43) Crangon affinis & Ps & -15.7 & 14.2 & 1 & $\mathrm{Jl}$ \\
\hline (44) Laomedia astacina & Pps & -17.2 & 12.0 to 12.9 & 2 & $\mathrm{Jl}$ \\
\hline (45) Nihonotrypaea japonica & Pps & $-17.2 \pm 0.3$ & $12.1 \pm 0.4$ & 36 & $\mathrm{Ja}, \mathrm{Mr}, \mathrm{Jl}$ \\
\hline (46) Upogebia major & $\mathrm{Pp}$ & $-17.9 \pm 0.4$ & $11.2 \pm 0.3$ & 12 & $\mathrm{Ja}, \mathrm{Mr}, \mathrm{Jl}$ \\
\hline (47) Pagurus dubius & $\mathrm{E}$ & $-14.2 \pm 0.5$ & $13.2 \pm 0.5$ & 6 & $\mathrm{Mr}, \mathrm{Jl}$ \\
\hline
\end{tabular}


Table 2 (continued)

\begin{tabular}{|c|c|c|c|c|c|}
\hline (48) Philyra pisum & Ps & $-16.0 \pm 0.3$ & $15.1 \pm 0.5$ & 6 & $\mathrm{Mr}, \mathrm{Jn}, \mathrm{Jl}$ \\
\hline (49) Charybdis japonica & Ps & -16.1 & 15.1 & 1 & Jn \\
\hline (50) Eriocheir japonicus & Pps & -18.6 to -17.1 & 13.0 to 13.7 & 2 & $\mathrm{Jn}$ \\
\hline (51) Hemigrapsus penicillatus & $\mathrm{E}$ & $-14.4 \pm 0.4$ & $13.4 \pm 0.5$ & 3 & $\mathrm{Jl}$ \\
\hline (52) Perisesarma bidens & Pps & -18.7 & 13.3 & 1 & $\mathrm{Jl}$ \\
\hline (53) Scopimera globosa & $\mathrm{E}$ & $-12.2 \pm 0.3$ & $11.7 \pm 0.2$ & 4 & $\mathrm{Jl}$ \\
\hline (54) Macrophthalmus abbreviatus & E & $-13.7 \pm 0.6$ & $12.7 \pm 0.7$ & 10 & $\mathrm{Mr}, \mathrm{Jl}$ \\
\hline (55) Macrophthalmus japonicus & E & $-13.2 \pm 0.4$ & $12.8 \pm 0.5$ & 3 & $\mathrm{Jl}$ \\
\hline $\begin{array}{l}\text { Holothuroidea } \\
\text { (56) Protankyra bidentata } \\
\text { Chordata }\end{array}$ & $\mathrm{Pp}$ & -16.7 to -15.5 & 10.8 to 11.8 & 2 & Mr, Jl \\
\hline $\begin{array}{l}\text { (57) Styela plicata } \\
\text { Osteichthyes }\end{array}$ & Pps & -18.3 to -18.0 & 12.4 & 2 & $\mathrm{Mr}$ \\
\hline (58) Taenioides cirratus & Ps & -16.8 & 15.6 & 1 & $\mathrm{Jl}$ \\
\hline (59) Periophthalmus modestus & Ps & $-14.6 \pm 0.8$ & $14.9 \pm 1.0$ & 4 & $\mathrm{Mr}, \mathrm{Jl}$ \\
\hline (60) Chaenogobius heptacanthus & Ps & $-16.5 \pm 0.6$ & $15.4 \pm 0.8$ & 4 & $\mathrm{Mr}, \mathrm{Jl}$ \\
\hline (61) Favonigobius gymnauchen & Ps & -15.5 to -14.4 & 14.7 to 15.3 & 2 & $\mathrm{Jl}$ \\
\hline (62) Eutaeniichthys gilli & Ps & -15.7 & 14.2 & 1 & $\mathrm{Mr}$ \\
\hline \multicolumn{6}{|l|}{ Primary producers or organic matter } \\
\hline Estuarine POM & & $-19.0 \pm 1.2$ & $7.3 \pm 0.4$ & 6 & $\mathrm{Mr}, \mathrm{Ag}$ \\
\hline Benthic microalgae & & $-14.7 \pm 1.8$ & $8.9 \pm 0.9$ & 3 & $\mathrm{Ja}, \mathrm{Mr}$ \\
\hline Seaweeds (all samples) & & $15.1 \pm 2.2$ & $10.4 \pm 2.2$ & 13 & $\mathrm{Ja}, \mathrm{Mr}, \mathrm{Jl}$ \\
\hline Enteromorpha intestinalis & & $-15.4 \pm 2.9$ & $9.2 \pm 1.0$ & 5 & $\mathrm{Mr}, \mathrm{Jl}$ \\
\hline E. compressa & & -13.7 & 16.3 & 1 & Ja \\
\hline E. linza & & $-14.3 \pm 2.0$ & $9.3 \pm 0.5$ & 3 & $\mathrm{Mr}$ \\
\hline Cladophora sp. & & -17.6 & 10.2 & 1 & $\mathrm{Mr}$ \\
\hline Porphyra yezoensis & & -16.7 & 12.4 & 1 & $\mathrm{Mr}$ \\
\hline Gracilaria lemaneiformis & & -14.3 to -14.1 & 10.6 to 12.1 & 2 & $\mathrm{Ja}, \mathrm{Mr}$ \\
\hline Reed (Phragmites communis) & & $-27.3 \pm 1.3$ & $7.8 \pm 0.8$ & 5 & $\mathrm{Ja}$ \\
\hline Detrital terrestrial plant material & & $-26.7 \pm 0.5$ & $1.7 \pm 1.0$ & 5 & $\mathrm{Jl}$ \\
\hline Riverine POM & & $-22.5 \pm 0.7$ & $4.7 \pm 1.9$ & 5 & $\mathrm{Ja}, \mathrm{Mr}, \mathrm{Jl}$ \\
\hline Sewage POM & & -25.1 to -25.0 & 6.6 to 6.8 & 2 & My \\
\hline Sedimentary organic matter (SOM) & & $-21.8 \pm 1.1$ & $5.0 \pm 1.8$ & 30 & $\mathrm{Mr}, \mathrm{Jl}$ \\
\hline${ }^{\mathrm{a}}$ Shell length $>25 \mathrm{~mm}{ }^{\mathrm{b}}$ shell length & & & & & \\
\hline
\end{tabular}

from the lowermost station on Transect A (Stn A1340) in March, where allochthonous sand had been spread. The extracted microalgae consisted of pennate diatoms such as Navicula spp., Amphora spp. and Nitzschia spp. (Table 1). The mean $( \pm \mathrm{SD}) \delta^{13} \mathrm{C}$ and $\delta^{15} \mathrm{~N}$ for benthic microalgae for the 3 samples were $-14.7 \pm 1.8 \%$ o (range $=-16.6$ to $-13.2 \%$ ) and $8.9 \pm 0.9 \%$ (range $=8.0$ to $9.9 \%$ ), respectively (Table 2 ).

Five species of the autochthonous seaweed (the green algae Enteromorpha intestinalis, E. compressa, E. linza and Cladophora sp., and the red alga Gracilaria lemaneiformis) and an allochthonous seaweed drifted from laver farm rafts lying offshore (the red alga Porphyra yezoensis) were obtained from the sandflat. Variability of $\delta^{13} \mathrm{C}$ and $\delta^{15} \mathrm{~N}$ within and between seaweed species was large. The isotopic values of E. intestinalis and E. linza collected on March 18 showed large variations among samples, with ranges from -17.6 to $-14.3 \%$ and from -16.7 to $-12.9 \%$ for $\delta^{13} \mathrm{C}$, and from 8.0 to $9.7 \%$ and from 8.9 to $9.8 \%$ for $\delta^{15} \mathrm{~N}$. The $\delta^{13} \mathrm{C}$ for all seaweed samples collected during the study period $(\mathrm{n}=13$ ) ranged from $-17.6 \%$ (Cladophora sp. in March) to $-10.8 \%$ (E. intestinalis in
July), while the $\delta^{15} \mathrm{~N}$ ranged from $8.0 \%$ (E. intestinalis in March) to $16.3 \%$ (E. Compressa in January). The mean $( \pm \mathrm{SD}) \delta^{13} \mathrm{C}$ and $\delta^{15} \mathrm{~N}$ for all seaweed samples were $-15.1 \pm 2.2 \%$ and $10.4 \pm 2.2 \%$, respectively, (Table 2).

The $\delta^{13} \mathrm{C}$ of the reed Phragmites communis ranged from -28.4 (live rootstock) to $-25.2 \%$ o (standing dead flowering head), while $\delta^{15} \mathrm{~N}$ ranged from 7.0 (live rootstock) to $8.9 \%$ (standing leaf) (Table 2). The mean $( \pm \mathrm{SD}) \delta^{13} \mathrm{C}$ and $\delta^{15} \mathrm{~N}( \pm \mathrm{SD})$ of the reed was $-27.3 \pm 1.3 \%$ and $7.8 \pm 0.8 \%$, respectively. Detrital terrestrial plant material that was found on the sandflat on July 12 had a mean $( \pm \mathrm{SD}) \delta^{13} \mathrm{C}$ of $-26.7 \pm$ $0.5 \%$ and a mean $( \pm \mathrm{SD}) \delta^{15} \mathrm{~N}$ of $1.7 \pm 1.0 \%$. The $\delta^{13} \mathrm{C}$ of riverine POM ranged from -23.4 to $-21.8 \%$, and $\delta^{15} \mathrm{~N}$ ranged from 2.1 to $6.8 \%$. In July, lower $\delta^{15} \mathrm{~N}$ values of 2.1 to $3.2 \%$ were found for riverine POM. An overall mean $( \pm \mathrm{SD})$ of riverine POM during the survey was $-22.5 \pm 0.7 \%$ for $\delta^{13} \mathrm{C}$ and $4.7 \pm 1.9 \%$ for $\delta^{15} \mathrm{~N}$. The $\delta^{13} \mathrm{C}$ and $\delta^{15} \mathrm{~N}$ of sewage POM were $-25.1 \%$ and $6.7 \%$, respectively.

Sediments obtained in March had a mean $( \pm \mathrm{SD}) \delta^{13} \mathrm{C}$ of $-20.8 \pm 0.4 \%$ o (range $=-21.5$ to $-20.3 \%$ ) and a mean 
$\Delta$ Tran. A (Mar) OTran. B (Mar) $\square$ Stn P (Mar) • Tran. B (Jul)
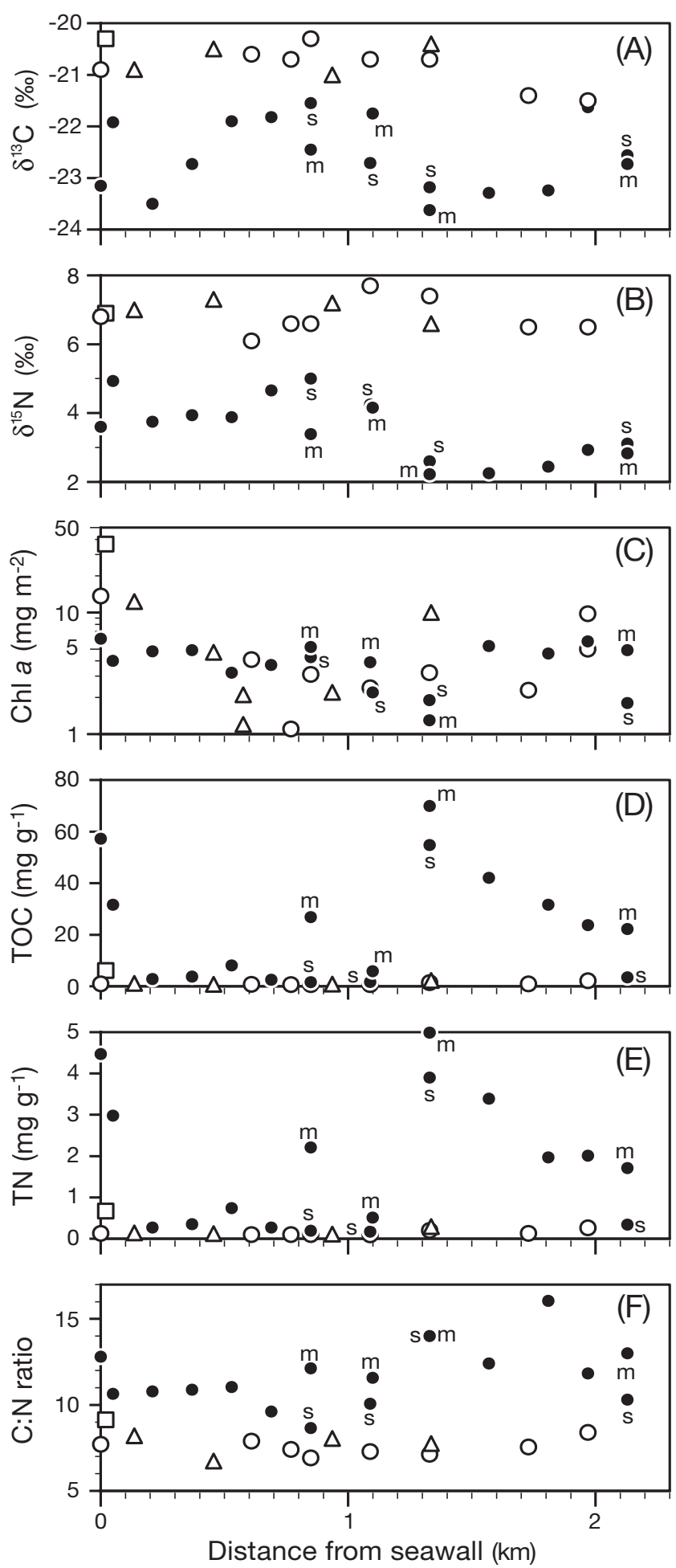

Fig. 2. Sandflat sediment. (A) $\delta^{13} \mathrm{C}$ and (B) $\delta^{15} \mathrm{~N}$ for sedimentary organic matter, (C) chlorophyll a, (D) total organic carbon (TOC), (E) total nitrogen (TN), and (F) C:N ratio in sediment along Transects A and B. Flood-derived mud (m) and the nearby basal sand (s) were sampled from each of the 4 stations with heterogeneous substrata
$( \pm \mathrm{SD}) \delta^{15} \mathrm{~N}$ of $6.9 \pm 0.4 \%$ o (range $=6.1$ to $7.7 \%$ ) (Fig. 2A,B). In July, both $\delta^{13} \mathrm{C}$ and $\delta^{15} \mathrm{~N}$ decreased over the whole range of the sandflat, and the values showed large variations among stations (mean $[ \pm \mathrm{SD}] \delta^{13} \mathrm{C}=$ $-22.6 \pm 0.7 \%$, range $=-23.6$ to $-21.6 \%$; mean $[ \pm \mathrm{SD}]$ $\delta^{15} \mathrm{~N}=3.5 \pm 0.9 \%$, range $=2.2$ to $5.0 \%$ ). The lowest $\delta^{13} \mathrm{C}$ and $\delta^{15} \mathrm{~N}$ values along transect $\mathrm{B}$ were found at stations 1300 to $1900 \mathrm{~m}$ from the seawall. The overall mean $( \pm \mathrm{SD}) \delta^{13} \mathrm{C}$ and $\delta^{15} \mathrm{~N}$ during the study period were $-21.8 \pm 1.1 \%$ ond $5.0 \pm 1.8 \%$, respectively (Table 2).

\section{Quantitative aspect of potential food sources}

Chl a concentrations in the river and estuarine waters in August are shown in Fig. 3. Chl a concentration in the river water was low $\left(1.1 \mu \mathrm{g} \mathrm{l}^{-1}\right)$, whereas over the sandflat (Stn d ) and at the offshore stations (Stns e - i) it was high (9.5 to $13.8 \mu \mathrm{g} \mathrm{l}^{-1}$ ). Chl a concentration at the uppermost shore Stn c was intermediate (7.4 $\mathrm{\mu g}^{-1}$ ) between that at the river Stn $\mathrm{b}$ and those at the offshore Stns d - i. Chl a concentration in the water column at Stn d was within the range of 12.9 to $18.1 \mu \mathrm{g}$ $\mathrm{l}^{-1}$, which was at the same level as at the offshore stations. The cumulative amount of chl a through the water column at the central part of the sandflat (mean water depth at high tides through the year $=2.8 \mathrm{~m}$ ) was estimated at $43.5 \mathrm{mg} \mathrm{m}^{-2}$, which was calculated by summing the chl a values obtained from the 4 sampling layers.

The range of chl a concentration in sediments was 1.1 to $36.7 \mathrm{mg} \mathrm{m}^{-2}$ in March and 1.3 to $6.1 \mathrm{mg} \mathrm{m}^{-2}$ in July (Fig. 2C). The highest content was observed from muddy sediment deposited on the concrete pavement close to the seawall (Stn P). Relatively high content was found at 2 lower-shore stations (Stns A1340 and B1970), where allochthonous coarse sediments had been spread, and at 2 upper-shore stations (Stns A140 and B0). If the 4 stations that had been modified by human activities (Stns P, A1340, B1970 and B2130) are excluded, chl a concentration scarcely exceeded $6 \mathrm{mg}$ $\mathrm{m}^{-2}$ (mean $\left[ \pm \mathrm{SD}\right.$ ] value in March $=4.4 \pm 4.2 \mathrm{mg} \mathrm{m}^{-2}$, in July $4.0 \pm 1.4 \mathrm{mg} \mathrm{m}^{-2}$ ). The overall mean $( \pm \mathrm{SD})$ of all measurements including the values at these 4 stations during the study period was $5.5 \pm 6.3 \mathrm{mg} \mathrm{m}^{-2}$.

Total organic carbon (TOC) and total nitrogen (TN) contents in sediments obtained in March were low, showing a range of 0.7 to $6.2 \mathrm{mg} \mathrm{g}^{-1}$ dry sediment for TOC and 0.1 to $0.7 \mathrm{mg} \mathrm{g}^{-1}$ for $\mathrm{TN}_{\text {; }}$ at most stations, TOC was $<1.5 \mathrm{mg} \mathrm{g}^{-1}$, and TN was $<0.2 \mathrm{mg} \mathrm{g}^{-1}$ (Fig. 2D,E). In July, TOC and TN contents increased remarkably, showing a range of 1.7 to $69.9 \mathrm{mg} \mathrm{g}^{-1}$ for TOC and 0.2 to $5.0 \mathrm{mg} \mathrm{g}^{-1}$ for TN. The highest contents were found at the uppermost-shore station (Stn B0) 

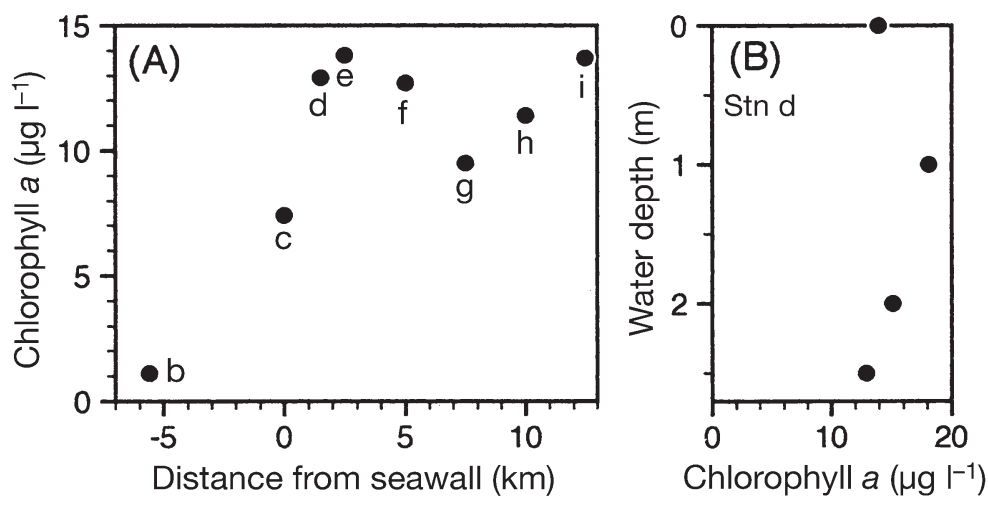

Fig. 3. Chlorophyll $a$ in water column. (A) Variation along the estuarine gradient (Stns b-i) in Fig. 1 in August 2003 and (B) vertical profile at the central part of the Shirakawa sandflat (Stn d) in August 2003

and stations 1.3 to $1.6 \mathrm{~km}$ from the seawall (Stns B1330 to $\mathrm{B} 1570)$. The $\mathrm{C}: \mathrm{N}$ ratio values also increased from 6.7 to 9.1 in March to 8.7 to 16.1 in July (Fig. 2F). High C:N ratios $>12.0$ were found from sediments at stations $>0.8 \mathrm{~km}$ from the seawall. A comparison between the muddy and sandy sediments at each station shows that the values of TOC, TN and C:N ratio obtained from the muddy ones were generally greater than those collected from the sandy ones.

\section{Isotopic compositions of intertidal animals}

A total of 62 species of animals were collected from the Shirakawa sandflat. Their mean $( \pm \mathrm{SD}) \delta^{13} \mathrm{C}$ and $\delta^{15} \mathrm{~N}$ during the study period is also shown in Table 2 . The range across all adult consumers was -21.5 (the dreissenid bivalve Peregrinamor ohshimai) to $-12.2 \%$ (ocypodid crab Scopimera globosa) for $\delta^{13} \mathrm{C}$ and $9.4(P$. ohshimai) to $15.6 \%$ (goby Taenioides cirratus) for $\delta^{15} \mathrm{~N}$. Isotopic compositions of the 4 main constituent species (bivalves Mactra veneriformis and Ruditapes philippinarum and thalassinidean shrimps Nihonotrypaea japonica and Upogebia major) were similar to each other; the range of $\delta^{13} \mathrm{C}$ for the 4 species was $-18.3(R$. philippinarum) to $-17.2 \%$ ( $N$. japonica), and the range of $\delta^{15} \mathrm{~N}$ was 10.7 (R. philippinarum) to $12.1 \%$ (N. japonica). However, juvenile $M$. veneriformis (shell length $<5 \mathrm{~mm}$ ), which were estimated to be recruited on the sandflat during the rainy season based on the growth rate on the Shirakawa sandflat $\left(=0.16 \mathrm{~mm} \mathrm{~d}^{-1}\right.$, A. Tamaki unpubl. data), were significantly (MannWhitney $U$-test, $\mathrm{p}<0.001)$ reduced in $\delta^{13} \mathrm{C}(-19.0 \pm$ $0.2 \%$ ) and $\delta^{15} \mathrm{~N}(8.3 \pm 0.1 \%$ o) relative to adult specimens $\left(\delta^{13} \mathrm{C}=-17.6 \pm 0.4 \%\right.$, $\delta^{15} \mathrm{~N}=11.4 \pm 0.4 \%$ ) .

Fig. 4 shows the mean $( \pm \mathrm{SD}) \delta^{13} \mathrm{C}$ and $\delta^{15} \mathrm{~N}$ for adults of the 4 main species and juveniles of Mactra veneriformis for each sampling occasion. There were signifi- cant differences for $\delta^{13} \mathrm{C}$ of adult $M$. veneriformis (Kruskal-Wallis test, $\mathrm{p}<0.001$ ) and for $\delta^{13} \mathrm{C}$ and $\delta^{15} \mathrm{~N}$ of Ruditapes philippinarum among the sampling occasions (Mann-Whitney $U$-test $\mathrm{p}<0.005$ ), but the differences between the minimum and maximum mean values were $\leq 0.4 \%$ o (Table 3). There were no significant differences for $\delta^{15} \mathrm{~N}$ of adult $M$. veneriformis and for $\delta^{13} \mathrm{C}$ and $\delta^{15} \mathrm{~N}$ of the 2 thalassinidean shrimps ( $N$. japonica and U. major) among the sampling occasions.

The $\delta^{13} \mathrm{C}$ and $\delta^{15} \mathrm{~N}$ of the other main intertidal animals collected on different occasions were also tested for temporal variations in their isotopic compositions (Table 3). There were significant differences for $\delta^{13} \mathrm{C}$ in the snail Reticunassa festiva, the clam Meretrix lusoria and the barnacle Balanus albicostatus and for $\delta^{15} \mathrm{~N}$ in $M$. lusoria and B. albicostatus among the sampling occasions, whereas the other 3 species (Pacific oyster Crassostrea gigas, bivalve Venatomya truncata and crab Macrophthalmus abbreviatus) showed no significant temporal variations in their $\delta^{13} \mathrm{C}$ and $\delta^{15} \mathrm{~N}$ values. Except for the $\delta^{13} \mathrm{C}$ of $M$. lusoria and B. albicostatus which showed large temporal variations (differences between minimum and maximum mean values $=1.3$ and $1.6 \%$, respectively), the differences between minimum and maximum mean values among sampling occasions were relatively small $(\leq 0.8 \%)$.

\section{DISCUSSION}

\section{Food sources for intertidal animals}

Stable isotope ratios of consumer organisms have been used to elucidate the trophic structure of various ecosystems (see reviews by Fry \& Sherr 1984, Owens 1987, Peterson \& Fry 1987). The stable-isotope approach is based on the assumption that there are a limited number of potential food sources, and that these food sources have isotopic compositions that are distinct from each other. In the study area, we examined allochthonous (i.e. riverine, estuarine and sewage POMs, reed and detrital terrestrial plant material) and autochthonous organic matter (i.e. benthic microalgae and seaweeds). These possible food sources could be distinguished from each other based on their $\delta^{13} \mathrm{C}$ and/or $\delta^{15} \mathrm{~N}$ values.

In general, terrestrial and marine organic matter show quite different $\delta^{13} \mathrm{C}$ values. Terrestrial organic matter usually originates from $\mathrm{C}_{3}$ plants, which have $\delta^{13} \mathrm{C}$ values ranging from -30 to $-23 \%$ with a modal value of about $-27 \%$ (e.g. Fry \& Sherr 1984, Boutton 

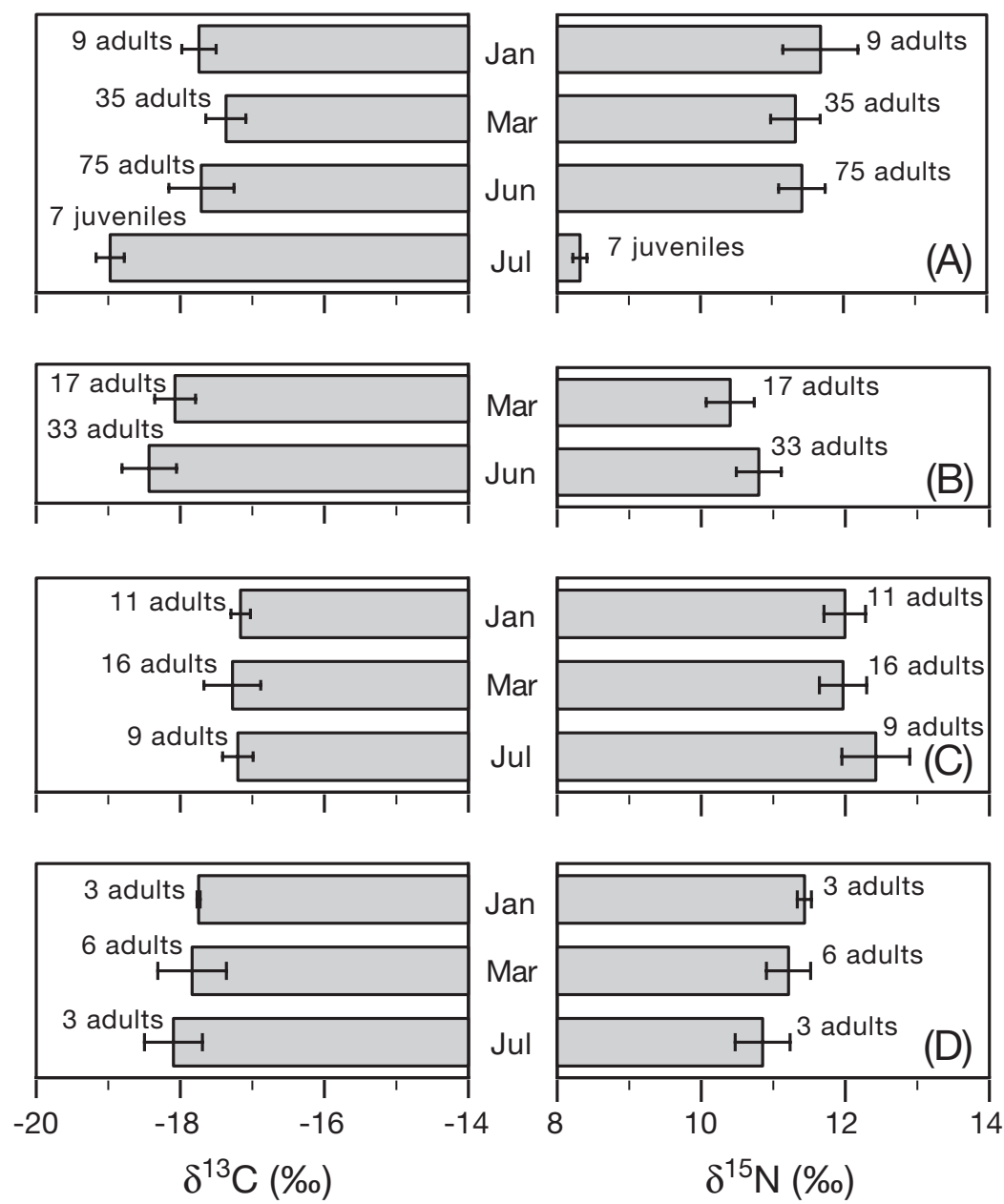

Fig. 4. Main species on Shirakawa sandflat. Mean $( \pm \mathrm{SD})$ values of $\delta^{13} \mathrm{C}$ (left column) and $\delta^{15} \mathrm{~N}$ (right column) for (A) Mactra veneriformis, (B) Ruditapes philippinarum, (C) Nihonotrypaea japonica, and (D) Upogebia major. Sample size (n) is given beside each bar

Table 3. Temporal variability in the $\delta^{13} \mathrm{C}$ and $\delta^{15} \mathrm{~N}$ for each of the main consumers inhabiting the Shirakawa sandflat. Difference of $\bar{X}=$ difference between minimum and maximum mean $\delta^{13} \mathrm{C}$ and $\delta^{15} \mathrm{~N}$ values on all sampling occasions. $\mathrm{p}=$ significance level of the difference in the $\delta^{13} \mathrm{C}$ and $\delta^{15} \mathrm{~N}$ among the sampling occasions

\begin{tabular}{|c|c|c|c|c|}
\hline Species & $\begin{array}{c}\delta^{13} \mathrm{C} \\
\text { Difference } \\
\text { of } \bar{X}(\%)\end{array}$ & $\mathrm{p}$ & $\begin{array}{c}\delta^{15} \mathrm{~N} \\
\text { Difference } \\
\text { of } \bar{X}(\%)\end{array}$ & $\mathrm{p}$ \\
\hline Reticunassa festiva & 0.7 & $0.033^{\mathrm{a}}$ & 0.3 & $0.207^{\mathrm{a}}$ \\
\hline Crassostrea gigas & 0.3 & $0.467^{\mathrm{a}}$ & 0.6 & $0.086^{\mathrm{a}}$ \\
\hline Mactra veneriformis ${ }^{\mathrm{c}}$ & 0.4 & $<0.001^{\mathrm{a}}$ & 0.3 & $0.261^{\mathrm{a}}$ \\
\hline Ruditapes philippinarum & 0.4 & $0.001^{\mathrm{b}}$ & 0.4 & $<0.001^{\mathrm{b}}$ \\
\hline Meretrix lusoria & 1.3 & $0.008^{b}$ & 0.8 & $0.008^{\mathrm{b}}$ \\
\hline Venatomya truncata & 0.4 & $0.267^{\mathrm{a}}$ & 0.3 & $0.406^{\mathrm{a}}$ \\
\hline Balanus albicostatus & 1.6 & $0.004^{\mathrm{b}}$ & 0.6 & $0.011^{\mathrm{b}}$ \\
\hline Nihonotrypaea japonica & 0.1 & $0.709^{\mathrm{a}}$ & 0.5 & $0.055^{\mathrm{a}}$ \\
\hline Upogebia major & 0.3 & $0.595^{\mathrm{a}}$ & 0.6 & $0.099^{\mathrm{a}}$ \\
\hline Macrophthalmus abbreviatus & us $\quad 0.6$ & $0.087^{\mathrm{b}}$ & 0.4 & $0.569^{\mathrm{b}}$ \\
\hline
\end{tabular}

1991) and $\delta^{15} \mathrm{~N}$ values ranging from -5 to $2 \%$ (e.g. Fry 1991); and marine organic matter in temperate regions, whose isotopic values are usually determined from POM, assuming that the bulk of POM is marine phytoplankton, has $\delta^{13} \mathrm{C}$ values ranging from -24 to $-18 \%$ with a modal value of about $-21 \%$ (e.g. Fry \& Sherr 1984, Gearing et al. 1984, Boutton 1991) and $\delta^{15} \mathrm{~N}$ values ranging from 3 to $12 \%$ (Mariotti et al. 1984, Owens 1987, Wada \& Hattori 1991). The $\delta^{13} \mathrm{C}$ and $\delta^{15} \mathrm{~N}$ values of estuarine POM in the study area (-20.0 to $-17.9 \%$ and 7.2 to $7.5 \%$, respectively), which was composed mainly of coastal phytoplankton, fell substantially within the respective ranges of the values given in the previous studies for marine organic matter. On the other hand, the isotopic compositions of POM collected from the 2 river stations showed higher values $\left(\delta^{13} \mathrm{C}=-23.4\right.$ to $-21.8 \%$, $\delta^{15} \mathrm{~N}=$ 2.1 to $6.8 \%$ ) than the common signatures of terrestrial organic matter. Taking into account that detrital terrestrial plant material carried by the river flow had $\delta^{13} \mathrm{C}$ and $\delta^{15} \mathrm{~N}$ values $(-26.7 \%$ and $1.7 \%$, respectively) falling within the range of the common values of terrestrial organic matter, the observed ${ }^{13} \mathrm{C}$ and ${ }^{15} \mathrm{~N}$ enrichment of the riverine POM was probably due to the mixture of organic matter derived from different origins. These may contain anthropogenic inputs including sewage and industrial effluents and/or agricultural runoff in addition to detrital terrestrial plant material.

The stable isotope approach is also based on a fixed isotopic enrichment between animals and their diets, that is, 0 to $1 \%$ for ${ }^{13} \mathrm{C}$ and 3 to $4 \%$ for ${ }^{15} \mathrm{~N}$ (reviewed by Peterson \& Fry 1987). The actual degree of fractionation, however, has been found to be quite variable (Gearing et al. 1984, Vander Zanden \& Rasmussen 2001, McCutchan et al. 2003). Yokoyama et al. (2005) experimentally found that the diet-tissue isotopic fractionation for Mactra veneriformis, Ruditapes philippinarum and Nihonotrypaea japonica, which are main constituent species on the Shirakawa sandflat, were $0.9,0.6$ and $2.0 \%$ 
for ${ }^{13} \mathrm{C}$, and 3.6, 3.4 and $3.9 \%$ for ${ }^{15} \mathrm{~N}$, respectively. The use of these values enables an accurate dietary reconstruction for the 3 species. The ranges of the expected $\delta^{13} \mathrm{C}$ and $\delta^{15} \mathrm{~N}$ values for the diet of the adults of these 3 species were -19.2 to $-18.3 \%$ and 7.0 to $8.1 \%$ in January and March, and -19.2 to $-18.6 \%$ and 7.4 to $8.5 \%$ in June-July, respectively (Fig. 5). If the diet-tissue fractionation for $N$. japonica is also applicable to a species of the same taxonomic group (Decapoda: Thalassinidea), Upogebia major, the expected diet of adults of this shrimp would have $\delta^{13} \mathrm{C}$ and $\delta^{15} \mathrm{~N}$ values of $-19.8 \%$ and $7.4 \%$ in January and March and $-20.1 \%$ and $6.9 \%$ in July, respectively. Thus, the isotopic values for the expected diet of these 4 species are tightly clustered, being close to the isotopic composition of estuarine POM (Fig. 5). This suggests that phytoplankton is the major food source and that seaweeds, benthic microalgae and riverine POM are minor contributors to the nutrition of these animals.

Of the 4 main species (Mactra veneriformis, Ruditapes philippinarum, Nihonotrypaea japonica and
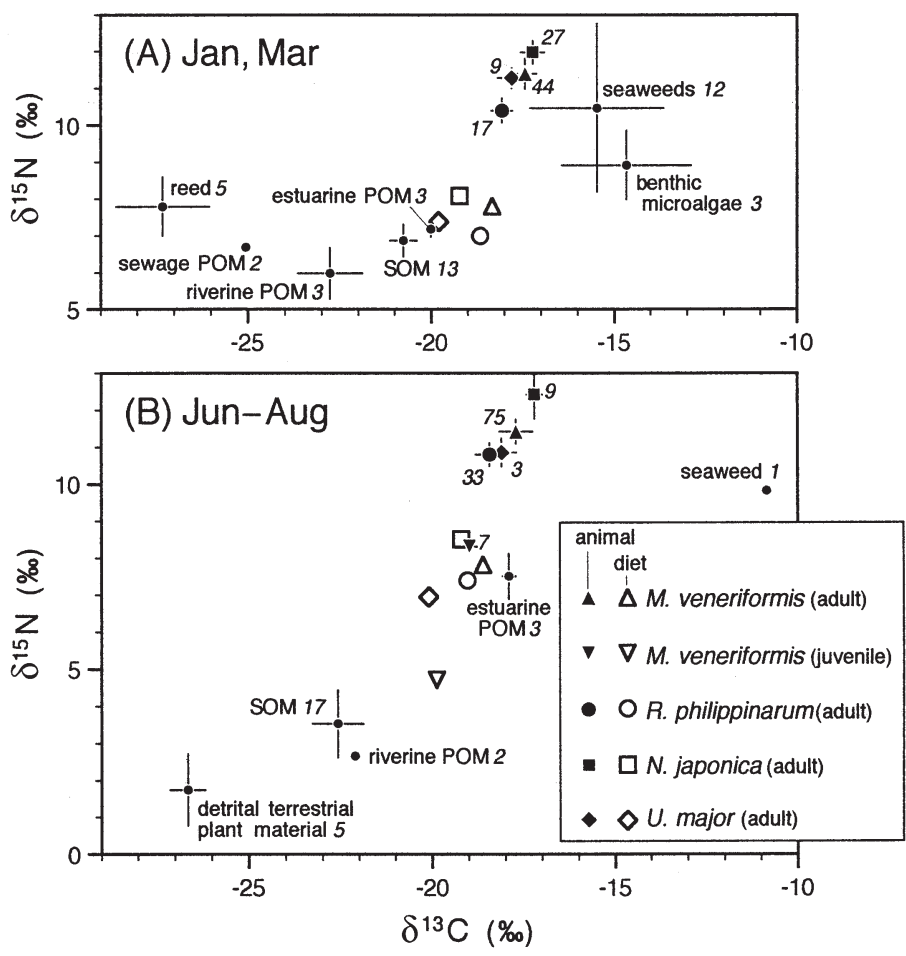

Fig. 5. Main species on Shirakawa sandflat. (A) January and March 2003 (before rainy season) and (B) June-August 2003 (during and immediately following rainy season). Dual isotope plots of $\delta^{13} \mathrm{C}$ and $\delta^{15} \mathrm{~N}$ for the 4 main species, their expected diets and potential food sources. See text and Yokoyama et al. (2005) for diet-tissue fractionation for each species to determine expected diets. The sewage POM samples were collected in May 2004. POM: particulate organic matter. SOM: sedimentary organic matter. Error bars are SD. Numerals denoted in italics indicate sample size (n)
Upogebia major), $N$. japonica had significantly enriched $\delta^{15} \mathrm{~N}$ values (Mann-Whitney $U$-test, p < 0.001). Taking into account the difference in the feeding mode between $N$. japonica and the other species, that is, deposit feeding by the former (Tamaki \& Ueno 1998) vs. suspension feeding by the latter (Hiwatari et al. 2002 for M. veneriformis; Nakamura 2004 for $R$. philippinarum; Kinoshita et al. 2003 for $U$. major), the higher $\delta^{15} \mathrm{~N}$ values for $N$. japonica may be a result of the incorporation of phytoplanktondependent primary consumers and/or phytoplanktonderived detritus, which have been shown to become enriched in ${ }^{15} \mathrm{~N}$ due to microbial transformation during decomposition (Wada 1980, Owens \& Law 1989).

The similarity of food sources among the 4 species suggests that these species would be involved in competition for trophic resources. Tamaki (2004a,b) reported that the population size and habitat range of these species had changed during the last $30 \mathrm{yr}$ : Ruditapes philippinarum occurred as the most dominant species over the entire sandflat during the 1970s; after the late 1970s, Nihonotrypaea japonica greatly increased its population size and might dominate the food resources in the upper half of the sandflat, together with $M$. veneriformis and $U$. major, whereas the $R$. philippinarum population was reduced, with its distribution confined to the lowest shore. Thus, regardless of the succession of dominant species, it is possible that the total biomass of the main constituents is limited within the carrying capacity of the habitat.

Mactra veneriformis juveniles obtained in the July survey had $\delta^{13} \mathrm{C}$ and $\delta^{15} \mathrm{~N}$ values reduced by $1.3 \%$ and $3.1 \%$, respectively, relative to adult specimens (Fig. 4). The $\delta^{13} \mathrm{C}$ and $\delta^{15} \mathrm{~N}$ of the juveniles' expected diet are $-19.9 \%$ and $4.7 \%$, respectively. These values are intermediate between the values of estuarine POM $\left(\delta^{13} \mathrm{C}=-17.9 \%, \delta^{15} \mathrm{~N}=7.5 \%\right)$ and riverine POM $\left(\delta^{13} \mathrm{C}=\right.$ $-22.1 \%$, $\delta^{15} \mathrm{~N}=2.7 \%$ ), suggesting that juvenile clams fed on a mixture of these POMs. In July, we found a large amount of muddy sediments that contained a high organic matter content with high $\mathrm{C}: \mathrm{N}$ ratios and reduced $\delta^{13} \mathrm{C}$ and $\delta^{15} \mathrm{~N}$ values (Fig. 2). We also found that the isotopic values of SOM on the sandflat were close to those of riverine POM (Fig. 5). These findings suggest that terrestrially derived organic matter carried by the Shirakawa River was deposited on the sandflat during the rainy season and that juvenile clams incorporated it in the form of riverine POM and/or SOM; however, the origin of the terrestrial organic matter (e.g. terrestrial plants, sewage and industrial effluents, and/or agricultural runoff) could not be specified in the present study, as mentioned earlier.

Several previous studies have suggested that significant incorporation of terrestrial organic matter by estu- 
arine animals occurs in the upper estuarine reaches (Incze et al. 1982, Kikuchi \& Wada 1996, Riera \& Richard 1996, Fry 1999) or during high freshwater discharge periods (Riera \& Richard 1997, Chanton \& Lewis 2002). A similar phenomenon was also found for adult populations of Mactra veneriformis and Ruditapes philippinarum in Ise Bay, central Japan (Kasai et al. 2004). However, we could not find any distinct reductions in the isotopic compositions of adult $M$. veneriformis in the rainy season (Fig. 4, Table 3).

Rossi et al. (2004) found that the $\delta^{13} \mathrm{C}$ values in the tellinid bivalve Macoma balthica decreased with body size. They regarded this tendency as a result of an ontogenetic shift in diet from benthic microalgae for juveniles to phytoplankton for adults. Hentschel (1998) suggested that the ontogenetic shift in diet in polychaetes was for the purpose of overcoming physiological constraints. When juveniles are physiologically limited in the maximum rate of food uptake compared to conspecific adults, they might rely on food sources of a higher quality to both minimize the amount of food and maximize energy uptake. In the present case, however, it is difficult to interpret the incorporation of riverine POM by Mactra veneriformis juveniles based on this hypothesis because terrestrial organic matter is usually rich in refractory compounds such as cellulose and lignin, suggesting a low nutritional value for estuarine animals (Fontugne \& Jouanneau 1987). The observed difference in the isotopic signature between juvenile and adult $M$. veneriformis may result from the recent feeding and the relatively long-term feeding history, respectively.

A dual isotope plot that incorporates all trophic components in the Shirakawa sandflat system is shown in Fig. 6. Each dot stands for the mean $\delta^{13} \mathrm{C}$ and $\delta^{15} \mathrm{~N}$ values for each of the consumers and for the mean $( \pm \mathrm{SD})$ values of their potential food sources during the study period (Table 2). The food-source members generally exhibited relatively large variability that was attributable to differences in sampling occasions, sampling sites or within and between species. By contrast, the majority of the main consumers did not show distinct seasonal variations in their isotopic values (Table 3), suggesting their long-term assimilation and low turnover rates of carbon and nitrogen. These findings assure that the use of the mean value from all samples for each consumer species is valid for illustrating the general trophic structure of the Shirakawa sandflat.

In analyses using a dual-isotope plot, often a food-chain structure is expressed as a line connecting points between a consumer and its diet, and the slope of this trophic-enrichment line is calculated as $\left(\delta^{15} \mathrm{~N}_{\text {animal }}-\delta^{15} \mathrm{~N}_{\text {diet }}\right) /\left(\delta^{13} \mathrm{C}_{\text {animal }}-\delta^{13} \mathrm{C}_{\text {diet }}\right) \quad$ (e.g. Riera et al. 1996, Kang et al. 1999). Among the experimentally obtained diet-tissue fractionation for the 3 species mentioned earlier (Ruditapes philippinarum, Mactra veneriformis, Nihonotrypaea japonica: Yokoyama et al. 2005), the largest value for the slope of the trophicenrichment line is $3.4 / 0.6=5.67$ ( $R$. philippinarum), and the smallest value is $3.9 / 2.0=1.95$ (Nihonotrypaea japonica). In Fig. 6, line $\alpha$ has a slope of 5.67 and starts from a point (mean $\delta^{13} \mathrm{C}$ of estuarine POM - $1 \mathrm{SD}$, mean $\delta^{15} \mathrm{~N}$ of estuarine POM $+1 \mathrm{SD}$ ) and line $\beta$ has a slope of 1.95 and starts from a point (mean $\delta^{13} \mathrm{C}$ of estuarine POM $+1 \mathrm{SD}$, mean $\delta^{15} \mathrm{~N}$ of estuarine POM $1 \mathrm{SD})$. Based on these 2 lines, the consumers are classified into 3 trophic groups; (1) those lying between lines $\alpha$ and $\beta$ (trophic group P in Table 2, comprising Pp, Pps and Ps), suggesting the incorporation of phytoplankton as a main food source, (2) those lying to the right of line $\beta$ (trophic group E), suggesting the incorporation of material more ${ }^{13} \mathrm{C}$-enriched than phytoplankton, and (3) those lying to the left of line $\alpha$ (trophic group R), suggesting the incorporation of material more ${ }^{13} \mathrm{C}$ reduced than phytoplankton. Of the total of 62 species analyzed, trophic groups P, E and R contained 51, 7 and 4 species, respectively. Thus, the majority of animals are concluded to obtain their nutrition directly or indirectly from phytoplankton.

The trophic levels of the phytoplankton (= TL 1)dependent consumers (= trophic group P in Table 2) could also be estimated from the range of the ${ }^{15} \mathrm{~N}$ fractionation for Ruditapes philippinarum, Mactra veneriformis and Nihonotrypaea japonica (3.4 to $3.9 \%$ ). In Fig. 6 , the consumers (P) are divided into 3 subgroups: (1) those lying between lines a $\left(\delta^{15} \mathrm{~N}=\right.$ mean value of estuarine POM $-\mathrm{SD}+3.4=10.3 \%$ ) and $b\left(\delta^{15} \mathrm{~N}=\right.$ mean $\left.+\mathrm{SD}+3.9=11.6 \%\right)$, which are regarded as phytoplankton-dependent primary consumers (Pp in Table 2 at trophic level TL 2), (2) those lying between lines $c\left(\delta^{15} \mathrm{~N}=10.3+3.4=13.7 \%\right)$ and $d$ $\left(\delta^{15} \mathrm{~N}=11.6+3.9=15.5 \%\right)$, which are regarded as phytoplankton-dependent secondary consumers (Ps at trophic level TL 3), and (3) those lying between lines $b$ and $c$, which are regarded as phytoplankton-dependent primary to secondary consumers (Pps at trophic level TL 2 to 3). Of these 51 species, 14 species, 16 species, and 21 species were grouped in the primary, secondary, and intermediate consumers between the primary and secondary ones, respectively (Table 2). No consumers exceeded the $\delta^{15} \mathrm{~N}$ of $15.6 \%$, indicating the phytoplankton-based trophic structure was composed of 3 trophic levels.

Seaweeds and benthic microalgae are potential food sources for members of trophic group E. However, the small difference in $\delta^{15} \mathrm{~N}$ between seaweeds and the members of this group (e.g. 0.3 to $1.3 \%$ differences for the deposit feeders such as Batillaria cumingii [No. 4 in Table 2 and Fig. 6], Urothoe sp. [No. 38] and Scopimera 


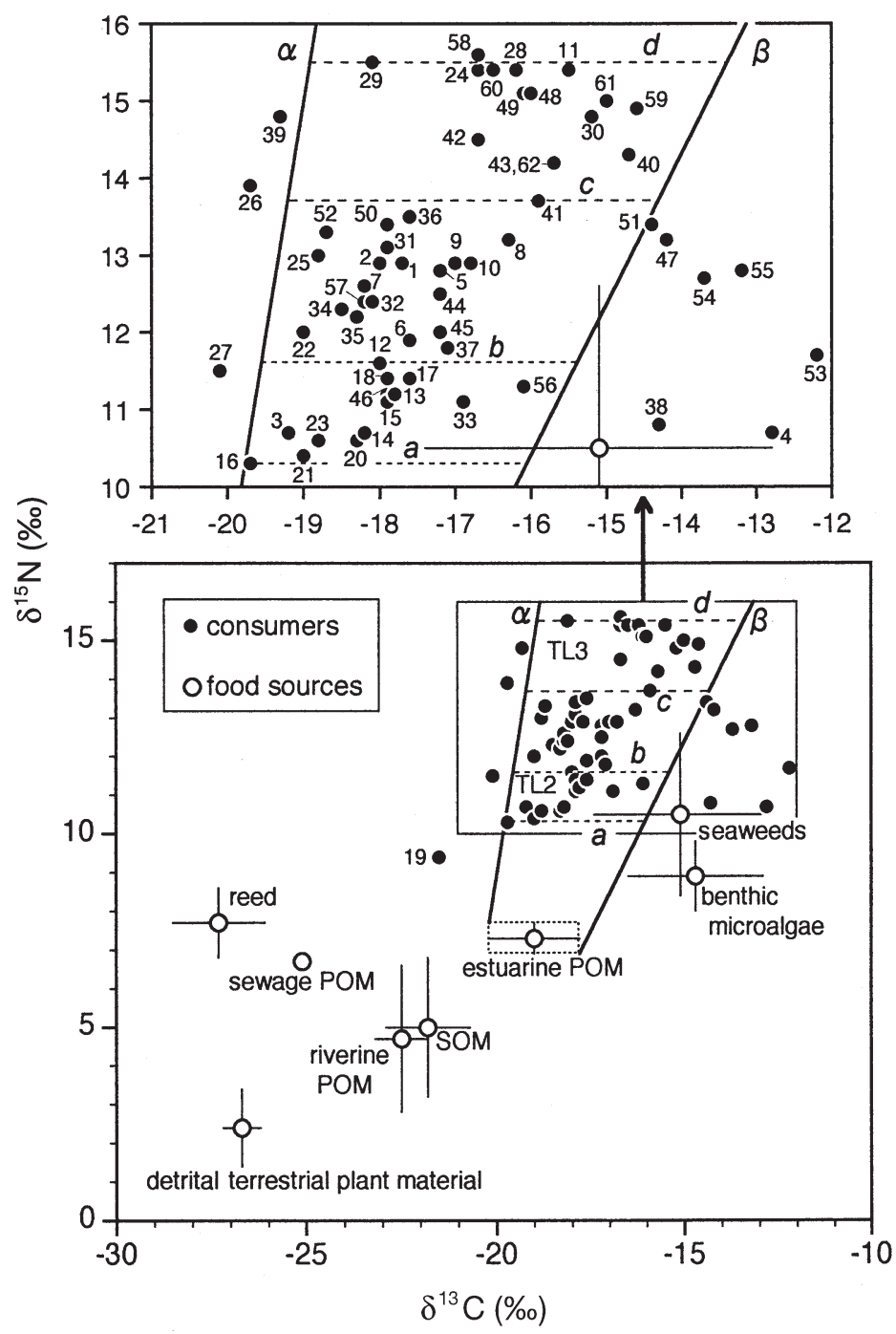

Fig. 6. Trophic structure in Shirakawa sandflat system. Dual isotope plot of $\delta^{13} \mathrm{C}$ and $\delta^{15} \mathrm{~N}$ for consumers and their potential food sources (Table 2). Dots: mean of all measurements during study period. Error bars are SD. Dotted lines: range of mean \pm SD for estuarine POM. TL: trophic level. See text for explanation of solid lines ( $\alpha$ and $\beta$ ) and dashed lines $(a-d)$. See Table 2 for species identification number (1-62)

globosa [No. 53], and 2.3 to $3.0 \%$ differences for the omnivores or carnivores such as Pagurus dubius [No. 47]; Hemigrapsus penicillatus [No. 51] and Macrophthalmus abbreviatus [No. 54]) implies that seaweeds played a lesser role in the nutrition of these animals. The enriched $\delta^{13} \mathrm{C}$ and reduced $\delta^{15} \mathrm{~N}$ for $B$. cumingii, Urothoe sp. and $S$. globosa suggest that benthic microalgae are a major component of their diet. In Fig. 6, P. dubius and H. penicillatus are located near line $\beta$, suggesting that these consumers depended on a mixture of phytoplankton and benthic microalgae.

Riverine POM is supposed to be assimilated by members of the trophic group R (Table 2, Fig. 6). How- ever, Eriopisa sp. (No. 39), Platynereis bicanaliculata (No. 26) and Tylorrhynchus sp. (No. 27) in this group are located near line $\alpha$ in Fig. 6, suggesting that these animals also derive a considerable part of their diet from phytoplankton sources. On the other hand, the bivalve Peregrinamor ohshimai (No. 19) had the lowest $\delta^{13} \mathrm{C}$ and $\delta^{15} \mathrm{~N}$ values of all consumers on the sandflat. Taking into account that this species is ectoparasitic on Upogebia major (No. 46) (Kato \& Itani 1995), which derives its nutrition from phytoplankton, we cannot conclude that the observed isotopic compositions indicate the assimilation of the riverine POM by this bivalve. $\delta^{13} \mathrm{C}$ values for the reed, detrital terrestrial plant material and organic effluents discharged from the sewage treatment plant were at least 5\% more negative than most of the intertidal animals, suggesting that these materials are not important food sources to members of the higher trophic levels on the sandflat.

Previous feeding experimental studies on coastal and estuarine animals have indicated that the diettissue isotopic fractionation is quite variable, ranging from -3.7 to $8.7 \%$ o for $\delta^{13} \mathrm{C}$ and from -0.7 to $5.8 \%$ for $\delta^{15} \mathrm{~N}$ (Yokoyama et al. 2005). As stated earlier, the estimation of the food sources for the consumers in the present study is based on the values experimentally established for the 3 main species. More information on the isotopic fractionation of other constituent species will be necessary to be able to fully interpret stable isotope data obtained in the field.

\section{Characteristics of the Shirakawa sandflat trophic structure}

Our results show that (1) the Shirakawa sandflat trophic structure depends for the most part on phytoplankton as a primary producer, and the trophic structure is composed of 3 trophic levels; (2) the 4 main constituent species (i.e. Mactra veneriformis, Ruditapes philippinarum, Nihonotrypaea japonica and Upogebia major) are phytoplankton-dependent primary consumers; (3) juveniles of $M$. veneriformis recruited during the rainy season could assimilate riverine POM; (4) only a few species derive a significant proportion of their nutrition from benthic microalgae; and (5) the reed, detrital terrestrial plant material, seaweeds and POM discharged from the sewage treatment plant are not food sources for the consumers.

A number of studies have shown that riverine terrestrial organic matter is of minor importance to the higher trophic levels in estuaries (e.g. Deegan \& Garritt 1997, Kang et al. 2003, Page \& Lastra 2003). Our isotopic measurements also revealed no evidence that terrestrial organic matter constitutes an important contribution to the diet of intertidal animals except for 
Mactra veneriformis juveniles. In general, terrestrial vascular plants contain large amounts of refractory compounds such as cellulose and lignin, which do not rapidly biodegrade, resulting in their accumulation in estuarine sediments. Most sedimentary organic matter is therefore of low nutritional value and not directly assimilable by benthic consumers (Cividanes et al. 2002). Kimura et al. (2002) assayed enzyme activities in a congeneric species of Nihonotrypaea japonica, $N$. harmandi, inhabiting sandflats in the outer part of Ariake Sound and suggested that labile, low-molecular-weight nitrogenous compounds in sediments serve as a principal source of nitrogen for this species. Our isotopic findings support these studies.

Recent isotopic studies have revealed some contribution of phytoplankton production to estuarine trophic structure (Sullivan \& Moncreiff 1990, Deegan \& Garritt 1997, Kang et al. 1999, 2003, Riera et al. 1999, Herman et al. 2000, Kurata et al. 2001, Chanton \& Lewis 2002, Takai et al. 2002, Hart \& Lovvorn 2003, Page \& Lastra 2003). Most of these studies, however, demonstrated that other primary producers such as benthic, epiphytic and epilithic microalgae also contribute to the secondary production. Recent interest has focused particularly on benthic microalgal production rather than pelagic primary production (Koike et al. 1992, Riera \& Richard 1997, Kang et al. 1999, Sauriau \& Kang 2000). Our findings that the macrobenthic community is almost totally dependent on coastal phytoplankton as the primary food source are in contrast to these reports.

\section{Factors generating the phytoplankton-based trophic structure}

A comparison of the relative abundances of benthic microalgae and phytoplankton may help to show that phytoplankton can be the basis of the trophic structure in the present study area. Cahoon (1999) summarized the maximum sediment $\mathrm{chl}$ a concentrations from a variety of locations and presented $128 \mathrm{mg} \mathrm{m}^{-2}$ as a mean value for temperate shores (water depth $=0$ to $5 \mathrm{~m})$. MacIntyre et al. (1996) and Underwood \& Kromkamp (1999) also reviewed pigment biomass in estuarine sediments and showed that most measurements had values $>20 \mathrm{mg} \mathrm{m}^{-2}$. The chl a concentrations measured for the sediments of the Shirakawa sandflat (range $=1.1$ to $36.7 \mathrm{mg} \mathrm{m}^{-2}$, mean [ $\pm \mathrm{SD}$ ] of all measurements $=5.5 \pm 6.3 \mathrm{mg} \mathrm{m}^{-2}$ ) indicate that the benthic microalgal biomass is much less than those in other localities. In general, benthic microalgal biomass in exposed sandy habitats is lower than that in sheltered, muddy habitats due to limited nutrients and the agitation of sand grains, which possibly damage algal cells (MacIntyre et al. 1996, Underwood \& Kromkamp
1999). Low-pigment biomass of benthic microalgae found in the present study area may be due to the high mobility of sediment particles, which probably results from the large tidal amplitude, rapid tidal current flows and/or strong seasonal wind-induced waves (Yamada \& Kobayashi 2004, F. Yamada et al. unpubl. data). The instability of habitats for benthic microalgae may also be due to coarse-grained inadhesive particles with high permeability and scarcity of nutrients in interstitial space, which originate from Yona, that is, the volcanic sand generated from Aso volcanoes (Suetsugi et al. 2002).

Ariake Sound is characterized by its eutrophic environments and great productivity of phytoplankton probably due to the semienclosed topography and inflow of a large amount of freshwater (yearly mean total flow rate of the 6 main rivers $=222 \mathrm{~m}^{3} \mathrm{~s}^{-1}$ ) that contains large amounts of nutrients originating from sewage, agricultural and industrial effluents (Kawaguchi et al. 2004, Matsuoka 2004, Watanabe et al. 2004). The comparison between the cumulative amount of chl a through the water column $(43.5 \mathrm{mg}$ $\left.\mathrm{m}^{-2}\right)$ and chl a concentration in sediments $\left(5.5 \mathrm{mg} \mathrm{m}^{-2}\right)$ of the Shirakawa sandflat in the present study indicates that the phytoplankton biomass greatly exceeds the benthic microalgal biomass. The relatively large biomass of phytoplankton and the scarcity of benthic microalgae may produce the phytoplankton-based trophic structure in this area.

Acknowledgements. We thank Mr. S. Ishikawa for helping to collect seawater samples, the Sewage Section of Kumamoto Municipal Office for permitting us to sample effluents from the sewage treatment plant, Dr. J. Ishizaka for providing his laboratory facilities for chl a concentration analysis, Dr. T. Ajisaka and Mr. K. Nishi for their assistance with identifying seaweed and macrobenthic species, and the Kumamoto Office of Rivers and National Highways for supplying data of the precipitation and flow rate of the Shirakawa River. This research was funded by the Japan Society for the Promotion of Science (JSPS) Grant-in Aid for Scientific Research 13854006 and 15570018.

\section{LITERATURE CITED}

Adin R, Riera P (2003) Preferential food source utilization among stranded macroalgae by Talitrus saltator (Amphipod, Talitridae): a stable isotopes study in the northern coast of Brittany (France). Estuar Coast Shelf Sci 56:91-98

Boutton TW (1991) Stable carbon isotope ratios of natural materials: II. Atmospheric, terrestrial, marine, and freshwater environments. In: Coleman DC, Fry B (eds) Carbon isotope techniques. Academic Press, San Diego, CA, p 173-185

Cahoon LB (1999) The role of benthic microalgae in neritic ecosystems. Oceanogr Mar Biol Annu Rev 37:47-86

Chanton J, Lewis FG (2002) Examination of coupling between primary and secondary production in a river-dominated estuary: Apalachicola Bay, Florida, USA. Limnol Oceanogr 47:683-697 
Cividanes S, Incera M, López J (2002) Temporal variability in the biochemical composition of sedimentary organic matter in an intertidal flat of the Galician coast (NW Spain). Oceanol Acta 25:1-12

Couch CA (1989) Carbon and nitrogen stable isotopes of meiobenthos and their food resources. Estuar Coast Shelf Sci 28:433-441

Créach V, Schricke MT, Bertru G, Mariotti A (1997) Stable isotopes and gut analyses to determine feeding relationships in saltmarsh macroconsumers. Estuar Coast Shelf Sci 44:599-611

Currin CA, Newell SY, Paerl HW (1995) The role of standing dead Spartina alterniflora and benthic microalgae in salt marsh food webs: considerations based on multiple stable isotope analysis. Mar Ecol Prog Ser 121:99-116

Deegan LA, Garritt RH (1997) Evidence for spatial variability in estuarine food webs. Mar Ecol Prog Ser 147:31-47

Fontugne MR, Jouanneau JM (1987) Modulation of the particulate organic carbon flux to the ocean by a macrotidal estuary: evidence from measurements of carbon isotopes in organic matter from the Gironde system. Estuar Coast Shelf Sci 24:377-387

Fry B (1991) Stable isotope diagrams of freshwater food webs. Ecology 72:2293-2297

Fry B (1999) Using stable isotopes to monitor watershed influences on aquatic trophodynamics. Can J Fish Aquat Sci 56:2167-2171

Fry B, Parker PL (1979) Animal diet in Texas seagrass meadows: $\delta^{13} \mathrm{C}$ evidence for the importance of benthic plants. Estuar Coast Mar Sci 8:499-509

Fry B, Sherr EB (1984) $\delta^{13} \mathrm{C}$ measurements as indicators of carbon flow in marine and freshwater ecosystems. Contrib Mar Sci 27:13-47

Gearing JN, Gearing PJ, Rudnick DT, Requejo AG, Hutchins MJ (1984) Isotopic variability of organic carbon in a phytoplankton-based, temperate estuary. Geochim Cosmochim Acta 48:1089-1098

Hart EA, Lovvorn JR (2003) Algal vs. macrophyte inputs to food webs of inland saline wetlands. Ecology 84: 3317-3326

Hentschel BT (1998) Intraspecific variations in $\delta^{13} \mathrm{C}$ indicate ontogenetic diet changes in deposit-feeding polychaetes. Ecology 79:1357-1370

Herman PMJ, Middelburg JJ, Widdows J, Lucas CH, Heip CHR (2000) Stable isotopes as trophic tracers: combining field sampling and manipulative labelling of food resources for macrobenthos. Mar Ecol Prog Ser 204:79-92

Hiwatari T, Kohata K, Iijima A (2002) Nitrogen budget of the bivalve Mactra veneriformis, and its significance in benthic-pelagic systems in the Sanbanse area of Tokyo Bay. Estuar Coast Shelf Sci 55:299-308

Incze LS, Mayer LM, Sherr EB, Macko SA (1982) Carbon inputs to bivalve mollusks: a comparison of two estuaries. Can J Fish Aquat Sci 39:1348-1352

Kang CK, Sauriau PG, Richard P, Blanchard GF (1999) Food sources of the infaunal suspension-feeding bivalve Cerastoderma edule in a muddy sandflat of Marennes-Oléron Bay, as determined by analyses of carbon and nitrogen stable isotopes. Mar Ecol Prog Ser 187:147-158

Kang CK, Kim JB, Lee KS, Kim JB, Lee PY, Hong JS (2003) Trophic importance of benthic microalgae to macrozoobenthos in coastal bay systems in Korea: dual stable C and N isotope analyses. Mar Ecol Prog Ser 259:79-92

Kasai A, Horie H, Sakamoto W (2004) Selection of food sources by Ruditapes philippinarum and Mactra veneriformis (Bivalva: Mollusca) determined from stable isotope analysis. Fish Sci 70:11-20
Kato M, Itani G. (1995) Commensalism of a bivalve, Peregrinamor ohshimai, with a thalassinidean burrowing shrimp, Upogebia major. J Mar Biol Assoc UK 75:941-947

Kawaguchi O, Yamamoto T, Matsuda O, Hashimoto T (2004) Determination of the limiting nutrients for growth of Nori laver and diatoms in Ariake Bay (Japan) by analyses of long-term variation in water quality. Oceanogr Jpn 13: 173-183 (in Japanese with English abstract)

Kikuchi E, Wada E (1996) Carbon and nitrogen stable isotope ratios of deposit-feeding polychaetes in the Nanakita River Estuary, Japan. Hydrobiologia 321:69-75

Kimura H, Harada K, Hara K, Tamaki A (2002) Enzymatic approach to fungal association with arthropod guts: a case study for the crustacean host, Nihonotrypaea harmandi, and its foregut fungus, Enteromyces callianassae. PSZN I: Mar Ecol 23:157-183

Kinoshita K, Wada M, Kogure K, Furota T (2003) Mud shrimp burrows as dynamic traps and processors of tidal-flat materials. Mar Ecol Prog Ser 247:159-164

Koike H, Saito T, Kosugi M, Kakino J (1992) Shell growth and diet of Tapes philippinarum from the tidal flats of the Obitsu River, Tokyo Bay. Fish Eng (Jpn) 29:105-112 (in Japanese with English abstract)

Kurata K, Minami H, Kikuchi E (2001) Stable isotope analysis of food sources for salt marsh snails. Mar Ecol Prog Ser 223:167-177

Lee SY (2000) Carbon dynamics of Deep Bay, eastern Pearl River estuary, China. II: Trophic relationship based on carbon- and nitrogen-stable isotopes. Mar Ecol Prog Ser 205: $1-10$

MacIntyre HL, Geider RJ, Miller DC (1996) Microphytobenthos: the ecological role of the 'secret garden' of unvegetated, shallow-water marine habitats. I. Distribution, abundance and primary production. Estuaries 19:186-201

Mariotti A, Lancelot C, Billen G (1984) Natural isotopic composition of nitrogen as a tracer of origin for suspended organic matter in the Scheldt estuary. Geochim Cosmochim Acta 48:549-555

Matsuoka K (2004) Changes in the aquatic environment of Isahaya Bay, Ariake Sound, west Japan: from the view point of dinoflagellate cyst assemblage. Bull Coast Oceanogr 42:55-59 (in Japanese with English abstract)

McCutchan JH Jr, Lewis WM Jr, Kendall C, McGrath CC (2003) Variation in trophic shift for stable isotope ratios of carbon, nitrogen, and sulfur. Oikos 102:378-390

Moncreiff CA, Sullivan MJ (2001) Trophic importance of epiphytic algae in subtropical seagrass beds: evidence from multiple stable isotope analyses. Mar Ecol Prog Ser 215: 93-106

Mulkins LM, Jelinski DE, Karagatzides JD, Carr A (2002) Carbon isotope composition of mysids at a terrestrial-marine ecotone, Clayoquot Sound, British Columbia, Canada. Estuar Coast Shelf Sci 54:669-675

Nakamura Y (2004) Suspension feeding and growth of juvenile Manila clam Ruditapes philippinarum reared in the laboratory. Fish Sci 70:215-222

Nakata H (2004) The environmental system of Ariake Sound and its present situation. In: Tamaki A (ed) Proceedings of the symposium on ecology of large bioturbators in tidal flats and shallow sublittoral sediments-from individual behavior to their role as ecosystem engineers. Nagasaki University, Nagasaki, p 67-70

Owens NJP (1987) Natural variations in ${ }^{15} \mathrm{~N}$ in the marine environment. Adv Mar Biol 24:389-451

Owens NJP, Law CS (1989) Natural variations in ${ }^{15} \mathrm{~N}$ content of riverine and estuarine sediments. Estuar Coast Shelf Sci 28:407-416 
Page HM, Lastra M (2003) Diet of intertidal bivalves in the Ría de Arosa (NW Spain): evidence from stable C and N isotope analysis. Mar Biol 143:519-532

Parsons TR, Maita Y, Lalli CM (1984) A manual of chemical and biological methods for seawater analysis. Pergamon Press, Oxford

Peterson BJ, Fry B (1987) Stable isotopes in ecosystem studies. Annu Rev Ecol Syst 18:293-320

Riera P, Richard P (1996) Isotopic determination of food sources of Crassostrea gigas along a trophic gradient in the estuarine bay of Marennes-Oléron. Estuar Coast Shelf Sci 42:347-360

Riera P, Richard P (1997) Temporal variation of $\delta^{13} \mathrm{C}$ in particulate organic matter and oyster Crassostrea gigas in Marennes-Oléron Bay (France): effect of freshwater inflow. Mar Ecol Prog Ser 147:105-115

Riera P, Richard P, Grémare A, Blanchard G (1996) Food source of intertidal nematodes in the Bay of MarennesOléron (France), as determined by dual stable isotope analysis. Mar Ecol Prog Ser 142:303-309

Riera P, Stal LJ, Nieuwenhuize J, Richard P, Blanchard G, Gentil F (1999) Determination of food sources for benthic invertebrates in a salt marsh (Aiguillon Bay, France) by carbon and nitrogen stable isotopes: importance of locally produced sources. Mar Ecol Prog Ser 187:301-307

Rossi F, Herman PMJ, Middelburg JJ (2004) Interspecific and intraspecific variation of $\delta^{13} \mathrm{C}$ and $\delta^{15} \mathrm{~N}$ in depositand suspension-feeding bivalves (Macoma balthica and Cerastoderma edule): evidence of ontogenetic changes in feeding mode of Macoma balthica. Limnol Oceanogr 49: 408-414

Sato M (ed) (2000) Life in Ariake Sea: biodiversity in tidal flats and estuaries. Kaiyusha, Tokyo (in Japanese)

Sato M, Koh CH (2004) Biological richness of the Asian tidal flats and its crisis by human impacts. In: Hong SK, Lee JA, Ihm BS, Farina A, Son Y, Kim ES, Choe JC (eds) Ecological issues in a changing world. Status, response and strategy. Kluwer, Dordrecht, p 135-155

Sauriau PG, Kang CK (2000) Stable isotope evidence of benthic microalgae-based growth and secondary production in the suspension feeder Cerastoderma edule (Mollusca, Bivalvia) in the Marennes-Oléron Bay. Hydrobiologia 440: 317-329

Suetsugi T, Fujita K, Suwa Y, Yokoyama K (2002) Influence of sediment transport on topography and bed material change at river mouth estuary. Tech Note Natl Inst Land Infrastruc Manage 32:1-169

Sullivan MJ, Moncreiff CA (1990) Edaphic algae are an important component of salt marsh food-webs: evidence from multiple stable isotope analyses. Mar Ecol Prog Ser 62:149-159

Suzuki R, Ishimaru T (1990) An improved method for the determination of plankton chlorophyll using $\mathrm{N}, \mathrm{N}-$ dimethylformamide. J Oceanogr Soc Jpn 46:190-194

Takai N, Mishima Y, Yorozu A, Hoshika A (2002) Carbon sources for demersal fish in the western Seto Inland Sea, Japan, examined by $\delta^{13} \mathrm{C}$ and $\delta^{15} \mathrm{~N}$ analyses. Limnol Oceanogr 47:730-741

Tamaki A (2004a) Ghost shrimps, snails, and clams on intertidal sandflats in the Ariake Sound estuarine system:

Editorial responsibility: Otto Kinne (Editor-in-Chief), Oldendorf/Luhe, Germany seeking for unified perspectives on their population explosions and declines. In: Tamaki A (ed) Proceedings of the symposium on ecology of large bioturbators in tidal flats and shallow sublittoral sediments-from individual behavior to their role as ecosystem engineers. Nagasaki University, Nagasaki, p 87-94

Tamaki A (2004b) Dynamics of benthic communities on intertidal sandflats in the Ariake Sound estuarine system, with special reference to the recent decline in the Manila clam yield. J Jpn Soc Water Environ 27:301-306 (in Japanese)

Tamaki A, Ueno H (1998) Burrow morphology of two callianassid shrimps, Callianassa japonica Ortmann, 1891 and Callianassa sp. (= C. japonica: de Man, 1928) (Decapoda: Thalassinidea). Crustac Res 27:28-39

Underwood GJC, Kromkamp J (1999) Primary production by phytoplankton and microphytobenthos in estuaries. In: Nedwell DB, Raffaelli DG (eds) Advances in ecological research, Vol 29. Estuaries. Academic Press, San Diego, CA, p 93-153

Vander Zanden MJ, Rasmussen JB (2001) Variation in $\delta^{15} \mathrm{~N}$ and $\delta^{13} \mathrm{C}$ trophic fractionation: Implications for aquatic food web studies. Limnol Oceanogr 46:2061-2066

Wada E (1980) Nitrogen isotope fractionation and its significance in biogeochemical processes occurring in marine environments. In: Goldberg ED, Horibe Y, Saruhashi K (eds) Isotope marine chemistry. Uchida-Rokakuho, Tokyo, p 375-398

Wada E, Hattori A (1991) Nitrogen in the sea: forms, abundances, and rate processes. CRC Press, Boca Raton, FL

Wainright SC, Weinstein MP, Able KW, Currin CA (2000) Relative importance of benthic microalgae, phytoplankton and the detritus of smooth cordgrass Spartina alterniflora and the common reed Phragmites australis to brackishmarsh food webs. Mar Ecol Prog Ser 200:77-91

Wardiatno Y, Shimoda K, Koyama K, Tamaki A (2003) Zonation of congeneric callianassid shrimps, Nihonotrypaea harmandi (Bouvier, 1901) and N. japonica (Ortmann, 1891) (Decapoda: Thalassinidea), on intertidal sandflats in the Ariake-Sound estuarine system, Kyushu, Japan. Benthos Res 58:51-73

Watanabe Y, Kawamura Y, Handa T (2004) Porphyra (or nori) aquaculture and nutrient condition in the Ariake Bay, Japan. Bull Coast Oceanogr 42:47-54 (in Japanese with English abstract)

Yamada F, Kobayashi N (2004) Annual variations of tide level and mudflat profile. J Waterw Port Coast Ocean Eng 130: 119-126

Yamamoto K, Suetsugi T, Fujita K, Yokoyama K (2003) Study on the sediment transport at estuary of the Shira River. Civ Eng J 45:30-35 (in Japanese)

Yelenik S, McClelland J, Feinstein N, Valiela I (1996) Changes in $\mathrm{N}$ and $\mathrm{C}$ stable isotope signatures of particulate organic matter and ribbed mussels in estuaries subject to different nutrient loading. Biol Bull (Woods Hole) 191: 329-330

Yokoyama H, Tamaki A, Harada K, Shimoda K, Koyama K, Ishihi Y (2005) Variability of diet-tissue isotopic fractionation in estuarine macrobenthos. Mar Ecol Prog Ser 296: $115-128$

Submitted: February 15, 2005; Accepted: May 31, 2005

Proofs received from author(s): November 14, 2005 